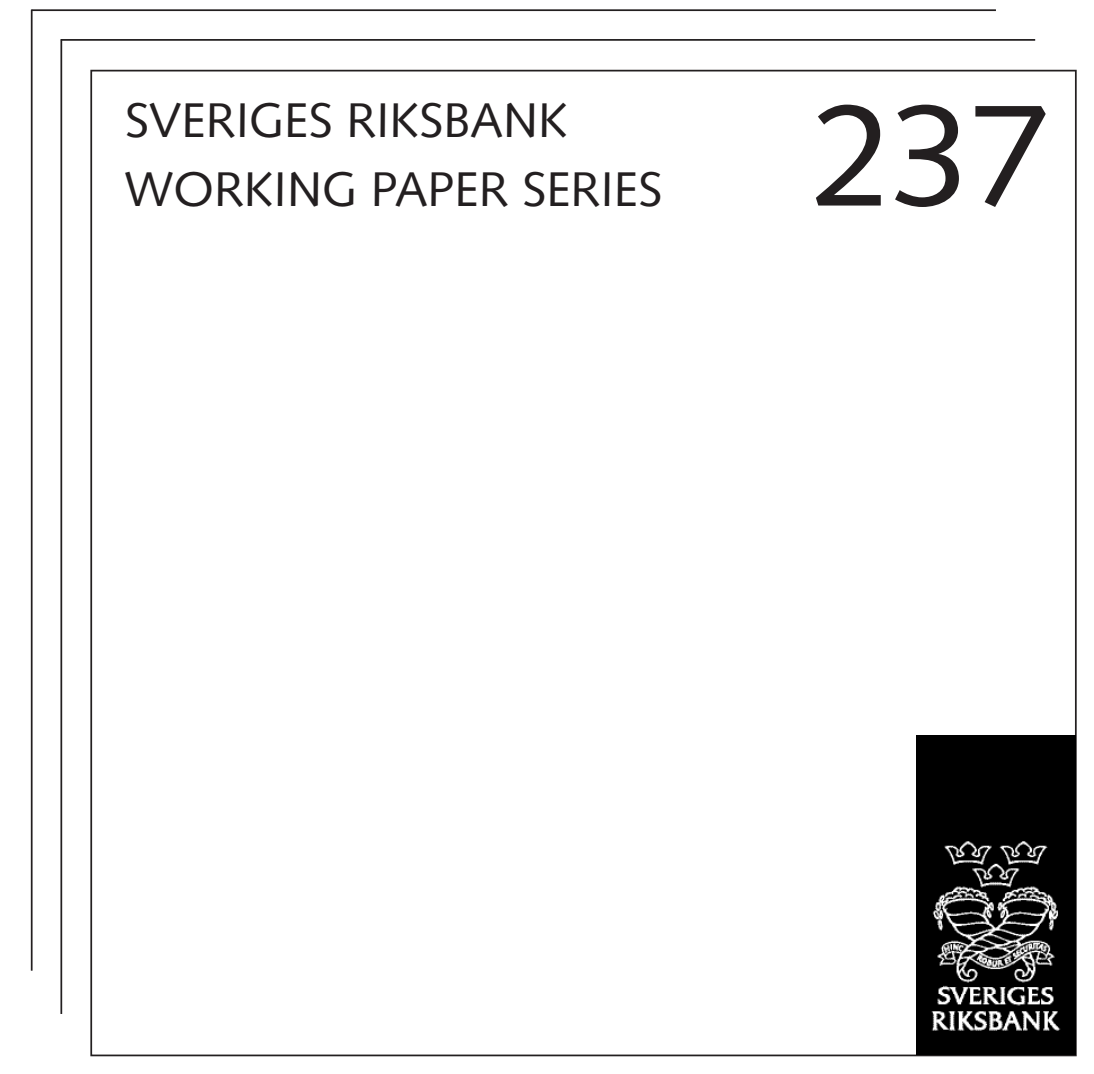

\title{
Picking the Brains of MPC Members
}

Mikael Apel, Carl Andreas Claussen and Petra Lennartsdotter 


\section{WORKING PAPERS ARE OBTAINABLE FROM}

Sveriges Riksbank •Information Riksbank • SE-103 37 Stockholm Fax international: +4687870526

Telephone international: +4687870100

E-mail: info@riksbank.se

The Working Paper series presents reports on matters in the sphere of activities of the Riksbank that are considered to be of interest to a wider public.

The papers are to be regarded as reports on ongoing studies and the authors will be pleased to receive comments.

The views expressed in Working Papers are solely the responsibility of the authors and should not to be interpreted as reflecting the views of the Executive Board of Sveriges Riksbank. 


\title{
Picking the Brains of MPC Members*
}

\author{
Mikael Apel ${ }^{\dagger}$, Carl Andreas Claussen ${ }^{\star}$ and Petra Lennartsdotter ${ }^{\S}$
}

Sveriges Riksbank Working Paper Series No. 237

\author{
January 2010
}

\begin{abstract}
This paper reports and analyzes the results from a questionnaire sent to all present and former members of the Riksbank's Executive Board, the monetary policy committee (MPC) of the Swedish central bank. The questions cover a number of issues discussed in the growing literature on monetary policy making by committees. The paper thus relates research to the views of practitioners in a way that has not been done before. We find, among other things, that many members consider the six-person strong Riksbank MPC to be slightly too large, that it is very common that members have decided before the policy meeting how they will vote, and that members, when forming their opinions, consider input from the staff more important than input from their colleagues.
\end{abstract}

Keywords: Monetary Policy Committee, Sveriges Riksbank, Questionnaire Study. JEL Code: D71, E52, E58.

\footnotetext{
* We would like to thank Björn Andersson, Ylva Hedén-Westerdahl, Lars Heikensten and Lars E O Svensson for comments and useful discussions. We would also like to thank present and former members of the Riksbank's Executive Board for having made this study possible by kindly responding to the survey. A special thanks to Irma Rosenberg for being willing to act as "test pilot" for the questionnaire. The views expressed in this paper are solely the responsibility of the authors and should not be interpreted as reflecting the views of the Executive Board of Sveriges Riksbank.

${ }^{\dagger}$ Monetary Policy Department, Sveriges Riksbank, S-103 37, Stockholm, Sweden. E-mail: mikael.apel@riksbank.se.

${ }^{*}$ Monetary Policy Department, Sveriges Riksbank. E-mail: carl-andreas.claussen@riksbank.se.

${ }^{\S}$ Monetary Policy Department, Sveriges Riksbank. E-mail: petra.lennartsdotter@riksbank.se.
} 


\section{Introduction}

There is a growing literature on monetary policy committees. In this literature researchers have tried to answer questions like "What is the optimal size of a monetary policy committee?", "Should the committee have external members?", "What is the role of the chairman?" and "Should the minutes from the monetary policy meeting be published?" There are theoretical and empirical results that shed some light on these issues, but many questions remain unresolved. ${ }^{1}$

However, what no one has done so far is to ask members of a monetary policy committee about their experiences and how they look upon issues discussed in the literature. This is somewhat surprising since in this research area it is indeed difficult to find a group of people more in the centre of events than MPC members. In this paper we report the results from a questionnaire that was sent to all the former and current members of the MPC of the Swedish central bank (Sveriges Riksbank), the Executive Board. The questions cover in different ways the above issues, as well as others that so far have received less attention in the literature. For example, the responses shed some light on the nature of the pooling process that precedes the decision, the role of the staff, and members' willingness to compromise about the interest rate decision. They also give some indication about the members' preferences for stabilising inflation vs. the output gap.

The paper is organized as follows. To put the results into a context and make them easier to interpret, the next section briefly describes some of the characteristics of the Riksbank's MPC. In Section 3, the survey and the sample are presented. The results are reported in Section 4 accompanied by brief reviews of the relevant research literature. Section 5 sums up and concludes. The questionnaire is enclosed in Appendix A.

\section{Some characteristics of the Riksbank's MPC}

The Riksbank adopted inflation targeting in 1993, but it was not until January 1999 that the objective of price stability was written into the law. At the same time, the Riksbank was given a more independent role in relation to its principal, the Swedish Parliament. This was manifested in, among other things, the establishment of an Executive Board with six full-time members, appointed for their skills in matters relevant for the Riksbank rather than their political affiliation.

The Executive Board is responsible for the Bank's entire operations (monetary policy, financial stability issues, market operations and the payment system), as well as for the Bank's administration and budget. This paper, as did the questionnaire, focuses on the Board's work on monetary policy. In what follows we refer to the Executive Board as the Monetary Policy Committee, the MPC.

\footnotetext{
${ }^{1}$ Overviews of the literature on monetary policy committees are found in, e.g., Blinder (2007) and Maier (2007).
} 


\subsection{The decision-making process}

Since 2008 the Riksbank's MPC normally decides on the instrument rate, the repo rate, six times a year. In the past, the frequency of decisions has been somewhat higher, seven to nine times a year 2000-2007. The decision-making process can briefly be described as follows. ${ }^{2}$ The process usually takes about six weeks. At an early stage the Monetary Policy Department comes up with a first forecast after a series of meetings. These meetings are mainly intended as working meetings for the staff at the Monetary Policy Department but the MPC members are invited to attend. The forecast is presented to the MPC and discussed at a larger meeting open to most of the Monetary Policy Department, where staff from other departments and advisors to the MPC also take part. The MPC discusses the forecast further and possibly adjusts it at a smaller meeting, and attempts to arrive at a forecast that it seems likely that a majority can support. Except for the MPC members, this smaller meeting is attended by a small number of people from the management of the Monetary Policy Department, representatives from the Communications Secretariat and advisors to the MPC. Based on the outcome from this meeting, the Monetary Policy Department compiles a first draft of the Monetary Policy Report/Monetary Policy Update. An editorial process then follows where the text gradually unfolds, and is regularly checked with the MPC members.

The interest rate decision is made at the monetary policy meeting by a majority vote. The Governor has the casting vote in case of a tie. The Monetary Policy Report/Update is published the day after the monetary policy meeting when the interest rate decision is made public. The report/update represents the majority view. Even though a complete draft is produced ahead of the policy meeting, last minute changes are possible.

\subsection{The role of transparency}

From the very beginning the MPC stressed the importance of transparency. To some extent the degree of transparency was regulated by the law, which for example stipulates that the Riksbank at least twice a year shall submit a written report to the Parliament's Committee on Finance. But the MPC has on its own initiative chosen a level of transparency well above the letter of the legislation.

At its first meeting on January 41999 the MPC decided that the minutes of the monetary policy meetings should be published. This has been done with a lag of about two weeks (since October 1999). It was also decided that after the meetings, a press release explaining the decision would be published. Press conferences would be held in connection with notable monetary policy adjustments, as well as when the Inflation Report were being published. The MPC members would furthermore make speeches, give interviews and write articles, the content of which would be the responsibility of the individual member. In terms of Blinder's (2004) taxonomy, the Riksbank's MPC is thus an individualistic committee.

The work towards greater transparency has since continued. The Inflation Report, which in its simplest form was first published in October 1993, has gradually evolved. In February 2007 it was replaced by the Monetary Policy Report which in addition to inflation and real-economy forecasts also contains a description of the monetary policy judgements. In particular, it contains the Riksbank's forecast of the future path of the instrument rate (the repo rate). ${ }^{3}$

\footnotetext{
${ }^{2}$ For a more detailed description, see Hallsten and Tägtström (2009).

${ }^{3}$ So far, instrument-rate paths are published only by a few central banks: The Reserve Bank of New Zeeland (since 1997), Norges Bank (the central bank of Norway) (since 2005), Sveriges Riksbank (since February 2007),
} 
Forecasts are now published six times a year instead of the earlier four times a year. On three occasions this takes the form of a Monetary Policy Report, and on the other three it takes the form of a Monetary Policy Update, which contains forecasts for a more limited number of central macroeconomic variables. Clarifications of the Riksbank's monetary policy framework have been published on two occasions, in February 1999 and in May 2006. The later publication describes the Riksbank's monetary policy strategy and is updated as the strategy evolves. A press conference is since May 2007 being held after every monetary policy meeting and not, as previously was the case, only when the repo rate is changed or an Inflation Report published. Also since May 2007, the minutes of the monetary policy meetings are attributed and show who has said what and not only how members have voted. In May 2009 the Riksbank began to publish the voting result directly after the monetary policy decision. If any of the MPC members have dissented, it is possible to see who and their main motivation for doing so already in the press release. The Riksbank is today ranked among the world's most transparent central banks (Dincer and Eichengreen 2007, 2009, Eijffinger and Geraats 2006).

\section{The survey and the sample}

We sent the questionnaire to all present and former members of the Riksbank' MPC after first having asked them if they were willing to participate. The members were informed that the individual responses would be treated confidentially. Since its initiation in 1999, altogether 13 people have served in the Riksbank's MPC. ${ }^{4}$ We received 12 responses.

The survey covers a number of issues, many of which are discussed in the growing literature on monetary policy committees. For most questions members were asked to grade a statement on a four-grade scale. For example, if a question concerned how often the member perceived that a particular event has occurred, the response alternatives were "never", "sometimes", "often" and "always". For some questions we wanted to compute the average response and we therefore coded the responses as $0,1,2$ and 3 .

For some of the issues we were interested to see whether matters have changed over time, i.e., if the views of a "recent" MPC differ form those of an "early" MPC. A potential watershed is when the Riksbank started to publish its own repo rate forecast in 2007. Four of the members, who had been in the MPC for at least two policy meetings both before and after this change, were asked to answer some questions twice: With respect to their experiences before the change, and in light of their most recent experiences.

The responses could then be divided into two subsamples: (i) a "pre-change" sample (nine responses) consisting of the responses from five members that have been in the MPC only before the own repo rate forecast and the "pre-change" responses from the four members that answered twice; (ii) a "post-change" sample (seven responses) consisting of the responses from three of the members that have been in the MPC only after the change and the "postchange" responses from the four members that answered twice.

Sedlabanki Islands (the central bank of Iceland) (March 2007-July 2008), and Czech National Bank (since 2008).

${ }^{4}$ Table A1 in Appendix B shows the members of the different MPCs 1999-2009. 
When presenting the results for the full sample of 12 members we use the most recent responses, i.e. the "post-change" responses, for the members that answered some questions twice.

\section{The results and relevant literature}

\subsection{The size and composition of the MPC}

Size

Internationally, the size of the monetary policy decision making bodies in central banks varies considerably, see Figure 1. In New Zealand and Israel, decisions are made by the Governor alone. In the UK the MPC has nine members. Outside of the inflation targeting group, the Federal Open Markets Committee (FOMC) of the Federal Reserve has 12 members while the Governing Council of the ECB has as many as 22 members. The mode of the distribution of MPC size is in the range of seven to nine members (see, for instance, Blinder 2009).

Figure 1. Size and composition of MPCs in inflation targeting countries

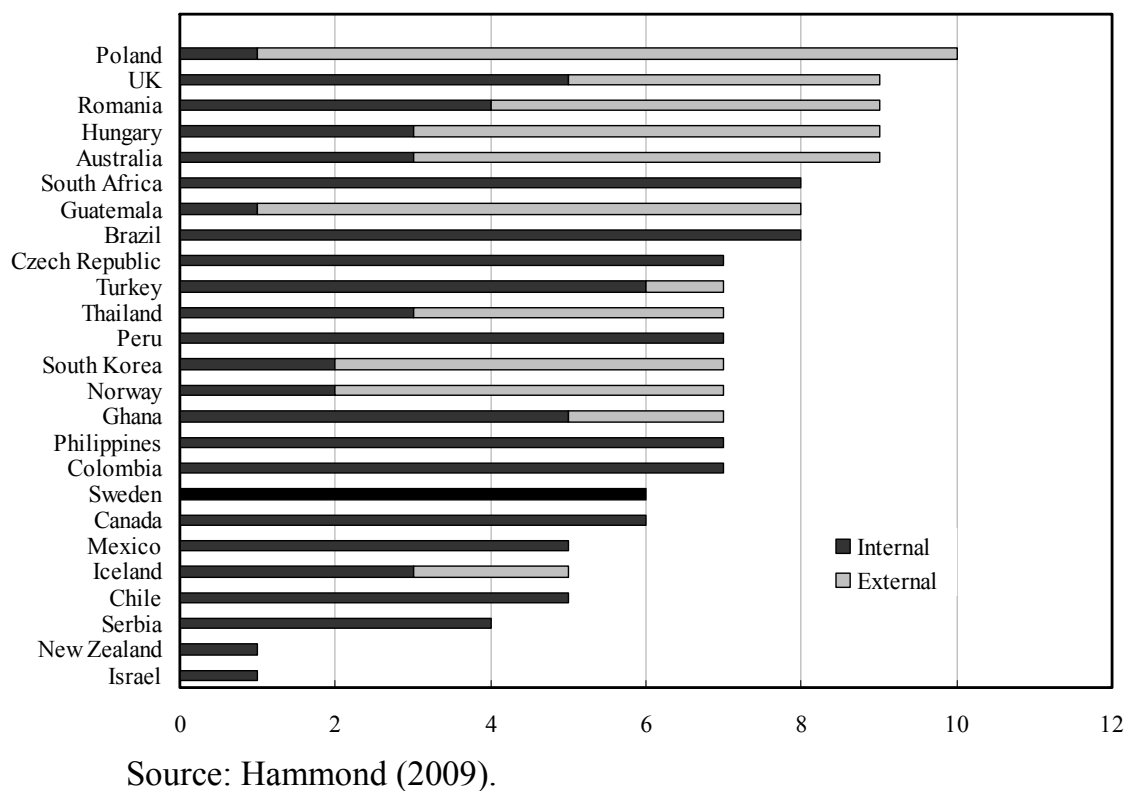

So what is the appropriate size of an MPC? If MPCs improve on decisions by pooling members' information and knowledge (see, e.g., Blinder 2007) this suggests in isolation that the bigger the committee, the better. But there are also costs associated with increasing the size of a committee. There might be coordination costs such as the decision process becoming more unwieldy and that a good monetary policy discussion is more difficult to conduct in an overly large committee. It might also be that effort of members decreases with committee size, free-riding, or simply that the bank's wage bill becomes unduly large.

The question of the optimal MPC size is addressed directly or indirectly in different strands of the literature. Experimental studies suggest that groups tend to make better monetary policy decisions than individuals (Blinder and Morgan 2005, 2008a, 2008b, Lombardelli, Proudman and Talbot 2005). More specifically, Blinder and Morgan (2008b) find that eight-person groups do not perform significantly better than four-person groups in implementing monetary policy tasks. 
In a review of the rather small economics literature on committees as well as the older and larger literature on committees in other social sciences, Sibert (2006) concludes that the ideal MPC may not have more than five members. In another interdisciplinary survey of studies, Erhart and Vasquez-Paz (2007) conclude that the optimal committee consists of roughly five to nine members. ${ }^{5}$ In simulations using a theoretical model of dynamic decision-making of a monetary policy committee Weber (2008) arrives at the conclusion that there is relatively little benefit of having a committee with more than seven members.

Other studies have tried to investigate whether there is a link between MPC size and macroeconomic performance. In a cross-country study, Erhart, Lehment and Vasquez-Paz (2007) find that inflation volatility tends to be higher in countries with MPCs with less than five members, but that raising the number of members above five does not reduce volatility further. Berger and Nitsch (2008) find a U-shaped relation between the MPC size and inflation, where the lowest level of inflation is reached with about seven to ten members.

The appropriate size of the MPC most likely varies with the specific conditions prevailing in different countries. Berger, Nitsch and Lybek (2008) find that countries that are larger and more heterogeneous, that have stronger democratic institutions, floating exchange rate regimes, and independent central banks with more staff tend to have larger boards. Erhart and Vasquez-Paz (2007) find, for example, that MPC size is positively related to the size of the country and to economic instability.

\section{Figure 2. MPC Size}

What do you believe to be the most appropriate number of members for the Riksbank's MPC, seen from a monetary policy perspective?

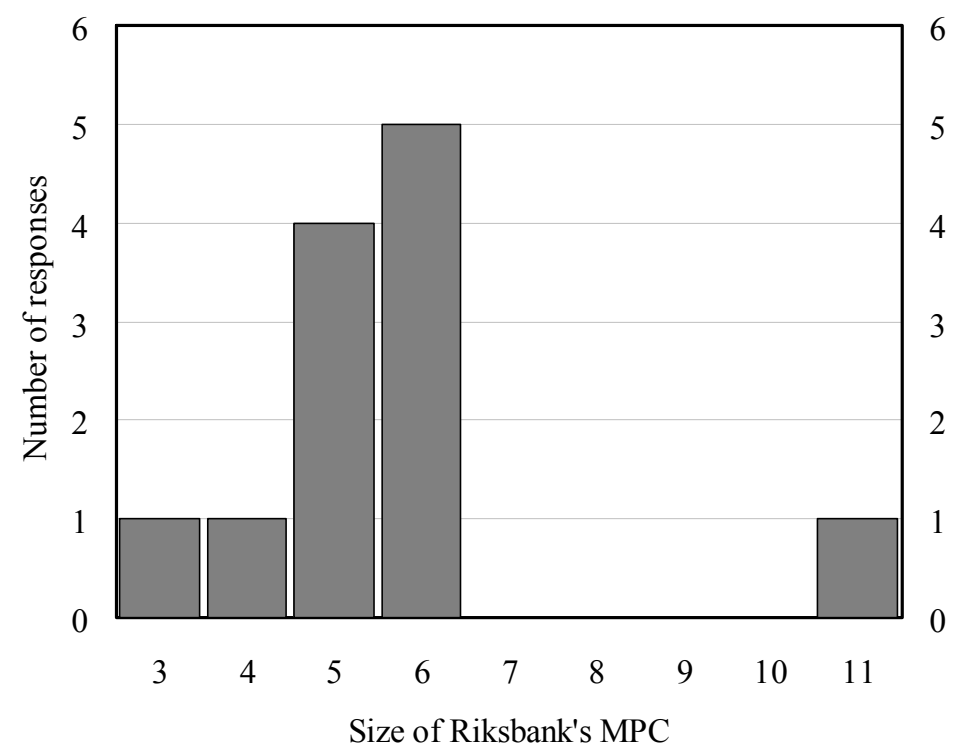

We asked the members what they believed to be the most appropriate size of the Riksbank's MPC from a monetary policy perspective. Half of the members thought that the present sixperson strong MPC was too big, see Figure 2. Some members gave two alternative answers,

\footnotetext{
${ }^{5}$ Gerling, Grüner, Kiel and Schulte (2005) survey the game theoretic literature on committee decision making with respect to, among other things, optimal committee size. They do not however conclude on a specific figure.
} 
for instance, " 3 or 5 " or " 6 but it could just as well be 5". In the figure the highest of these alternatives are shown. If one instead uses the lowest alternatives, a majority would prefer a smaller MPC. Many of the respondents also specifically commented that they would prefer an odd number of members, suggesting that they are not all that content with the arrangement that the Governor has the casting vote.

\section{Composition}

As is apparent from Figure 1, it is not only the size of the MPC that varies between countries but also the composition. Many MPCs have external members. In Bank of England, for instance, four out of nine members are external. In the Riksbank all MPC members are internal.

Why have external members? In the Bank of England, the purpose is "to ensure that the MPC benefits from thinking and expertise in addition to that gained inside the Bank of England". A large literature, mostly in social psychology, points to another potential reason, the danger of polarization and "group-think". Numerous empirical and experimental studies in other fields than economics looking at decision making by groups find that group deliberation sometimes results in a mean opinion that is more extreme than the group's mean original position (Sibert 2006), a phenomenon called "group-polarization". A detrimental form of group polarization called "group-think" occurs when committee members' strive for consensus makes them stop paying sufficient attention to alternative courses of action. The committee may then make worse decisions than any of its members would have made on their own. Sibert (2006) argues that external members help in avoiding group-polarization.

If external members systematically differ from internal members this should be reflected in a different voting pattern. A number of studies using voting data from the Bank of England's MPC do indeed find that the external members act somewhat differently by, for example, dissenting against policy rate decisions more often, tending to prefer lower policy rates than the internal members, and by being more active in the sense that they have a higher probability to vote for a change of the interest rate (see, for instance, Gerlach-Kristen 2003, 2009, Groth and Wheeler 2008, Hansen and McMahon 2008, and Harris and Spencer 2008). Besley, Meads, and Surico (2008), however, find no significant differences between external and internal members in their reactions to the forecasts of inflation and output gaps.

We asked the MPC members of their view on two statements regarding external members:

- External members could contribute information, knowledge and an "external" perspective that would otherwise not be taken into account.

- If one or more of the six members of the Riksbank's MPC was employed part-time this would require less resources without the monetary policy decision being of poorer quality.

The responses suggest that there is scepticism towards a framework with external members, although there is some variation in the responses, see Figure 3. One possible explanation is that the members consider the preparatory process described above, with an intensive interaction with the Riksbank staff and within the MPC, to be crucial. It may be seen as difficult for external members to fully participate in this process. A more negative interpretation is that the MPC members underestimate the danger of group polarization and simply tend defend the prevailing order (even though they did not defend the prevailing order regarding committee size). 


\section{Figure 3. External members}

How well do you think the following statements apply?

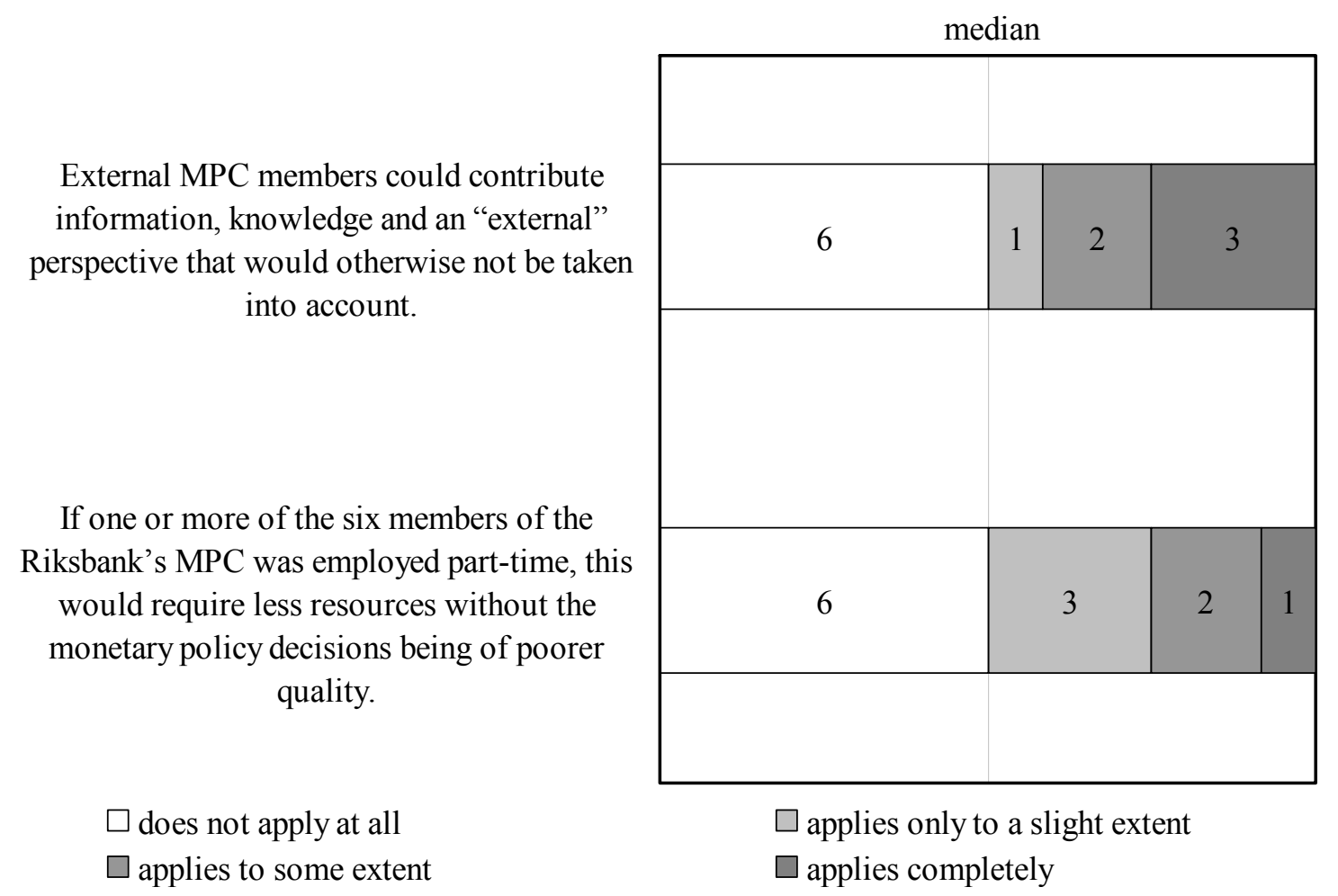

\subsection{The nature of pooling and the role of the staff}

Although the members have different views on exactly how large the Riksbank's MPC should be, they seem to agree that monetary policy decisions are best made by a group of people. They thus appear to assume that knowledge and skills of individuals can somehow be pooled, resulting in better decisions. We find it useful to distinguish between "pooling by talking" and "pooling by voting" (Claussen, Matsen, Røisland and Torvik 2009). Pooling by talking takes place when the MPC members deliberate. Pooling by voting is the implicit pooling that takes place when the MPC votes or uses some other aggregation mechanism to aggregate the different proposals into a decision. In the survey we asked the members to judge the importance of the two types of pooling. Perhaps not very surprisingly, members found them both important. ${ }^{6}$

If pooling by talking is important, what kind of exchange takes place between the MPC members? To learn more about this we asked the members how important contributions from colleagues in the MPC have been for their own assessments regarding three different aspects:

(i) The current economic situation and trends that the Riksbank is unable to influence, such as future oil prices and international economic developments.

\footnotetext{
${ }^{6}$ Survey questions 1.3 and 1.4. For further details see Apel, Claussen and Lennartsdotter (2010).
} 
(ii) How the Swedish economy functions and thereby how things will develop if the Riksbank acts in one particular way or another.

(iii) How quickly inflation should be brought back on target/prioritising between stabilising inflation and stabilising the real economy.

In more technical terms this categorization can be said to represent (i) exogenous variables; (ii) the model and (iii) the preferences regarding stabilising inflation relative to stabilising the real economy (the relative weights in the monetary policy objective function).

Although there has been a significant increase in the research on MPCs in recent years, the role of the staff in the decision making process has received remarkably little attention. The staff has a potentially very important role in that it typically gathers, filters and structures information which it passes on to the MPC. The implicit assumption in much of the literature, however, seems to be that MPC members gather their own information, that they have their own "model" of the economy and, based on this and their preferences - and possibly discussions with their MPC colleagues - make their policy choices. We asked the members how important they perceive contributions from the staff to be for their own assessments of (i)-(iii).

For all three categories the most common response was that the MPC colleagues were only "slightly important", see Figure 4. The colleagues' possibilities to influence one another's decisions thus appear rather limited. This result is somewhat at odds with the view that "pooling by talking" is important. In contrast, the responses indicate that the staff plays a crucial role for the members' assessments. A large majority of the members considered the staff to be very important for their own assessment of (i) and (ii). The staff is however less important for the members' assessment of how quickly inflation should be brought back on target, category (iii). This is quite natural and supports the notion that the members' deliberations in this respect reflect their personal preferences (we will return to this issue later on).

\section{Figure 4. Pooling}

How important were your colleagues in the MPC/the staff...

i)... as sources of information on the current economic situation and on developing trends that the Riksbank is unable to influence, such as the way the oil price and international economic activity develop?

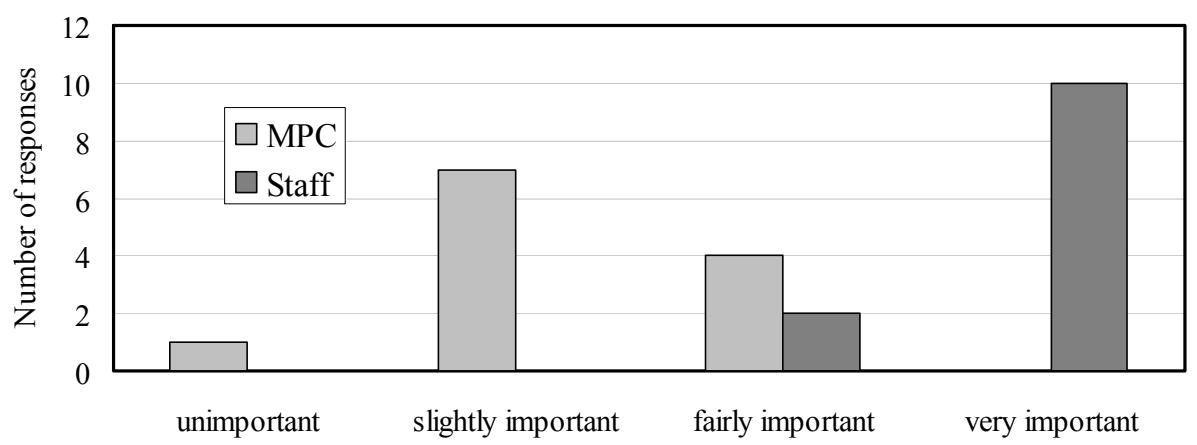


ii)...for your view on how the Swedish economy functions and thereby how

things will develop if the Riksbank acts in one particular way or another?

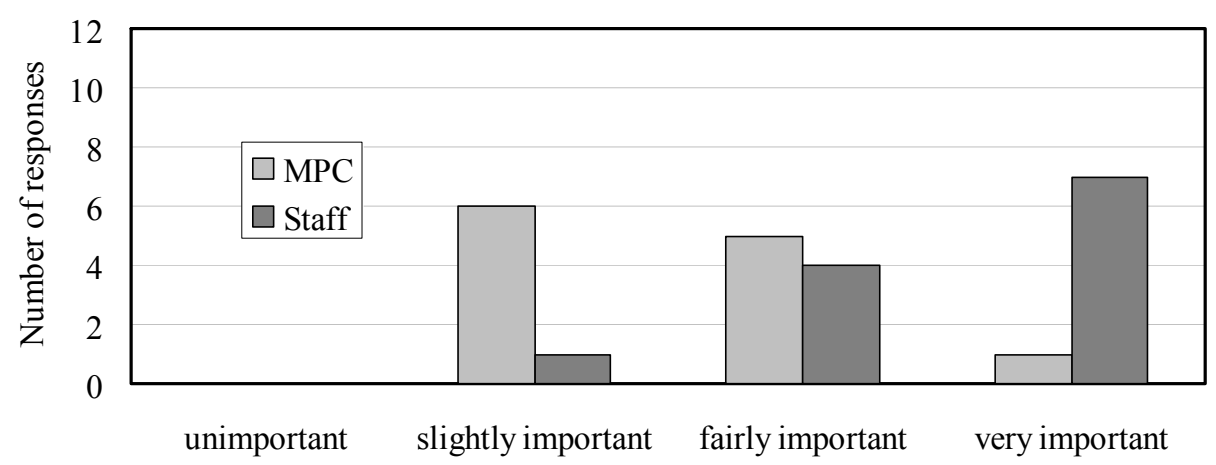

iii)...for your assessment of how quickly inflation should be brought back on target/prioritising between stabilising inflation and stabilising the real economy?

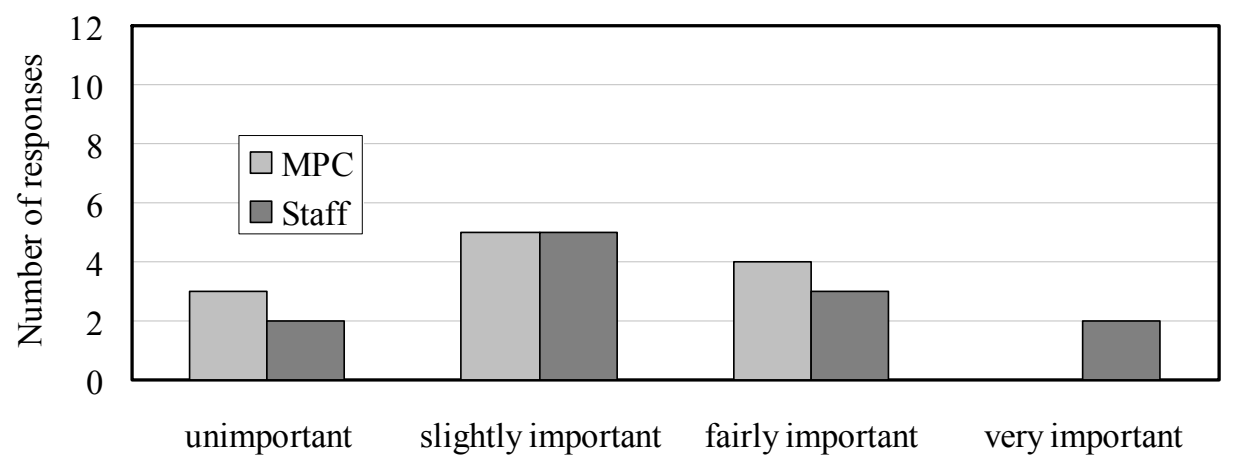

\subsection{Before the meeting: How much of the puzzle is already completed?}

While much of the focus in the research literature is on the monetary policy meeting, less is known about the state of matters before the meeting. The discussion at the policy meeting hardly starts from scratch, but how much of the puzzle is actually already completed before the meeting? To obtain more information about this, we asked the members to specify, for instance, how often they had decided how they would vote prior to the monetary policy meeting, and how often they had a firm idea in advance of the other members' views.

This issue relates to a strand of the literature that explores why MPC members may want to meet and discuss, and possibly settle things, before the monetary policy meeting, away from the public eye (see for example Swank and Visser 2008 and Swank, Swank and Visser 2008). A hypothesis is that MPC members would like to reach a deal at an informal pre-meeting to be able to show a united front favouring the decision at the formal monetary policy meeting. The reason being that disagreement may signal lack of competence since competent members are presumed to make the same assessment. And even if the members not necessarily would like to show a united front they might, as expressed by Greenspan, "be concerned that their half-thought-through, but nonetheless potentially valuable, notions would... be made public." (as cited in Meade and Stasavage 2008, p.74). 
The questions we posed and the members' responses are shown in Figure 5. The results indicate that most of the pieces are indeed in place prior to the meeting. The majority of the members have always decided beforehand how to vote, always have a firm idea of how the majority of their colleagues intend to vote, and often also a clear impression of how all of their colleagues intend to vote. It is quite unusual that new information or arguments come up at the monetary policy meeting.

\section{Figure 5. The situation before the meeting}

How often has it happened that...

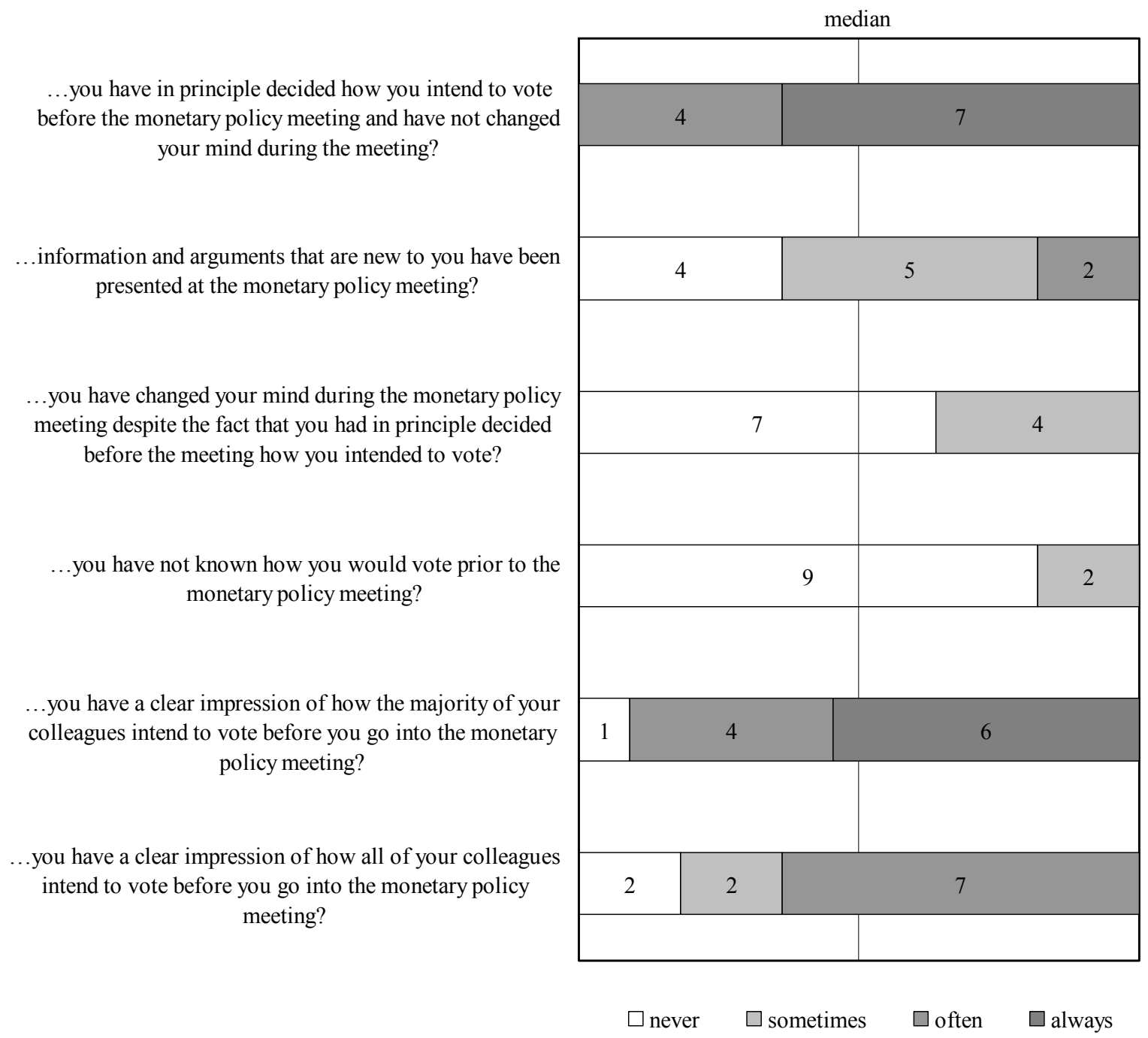

As we noted above, the Riksbank began to publish its own forecast for the repo rate in February 2007. This made the monetary policy process, with preparatory meetings and interaction with the staff and within the MPC, even more intense and comprehensive than it was before. One hypothesis is thus that the "post-change" sample perceives that even more is in place prior to the monetary policy meeting than does the "pre-change" sample.

The results appear to support the hypothesis. The members of the "post-change" sample had more often decided how they would vote prior to the monetary policy meeting (the average 
scores was 3.0 compared to 2.4 for the "pre-change" sample) and more often had a firm idea both of how the majority of their colleagues would vote (2.7 compared to 2.0$)$, as well as how all of the others would vote (1.8 compared to 1.1). The "post-change" sample also considered that new information and new arguments were more rarely put forward at the monetary policy meetings $(0.7$ compared to 1.0$)$, more rarely changed their minds during the meeting $(0$ compared to 0.4$)$ and were more rarely uncertain as to how they would vote (0 compared to $0.3)$.

Our interpretation of the result that much of the puzzle is completed before the policy meeting is not that it reflects an ambition to achieve consensus beforehand, nor that it is a way to hide from the public eye (representatives of the principal, the Chairman and Vice Chairman of the Governing Council, are invited to attend the preparatory meetings). Rather, meetings where the MPC members discuss with the staff and among each other and more or less explicitly express their views are a natural and necessary part of the forecasting process. As stated by Svensson (2009a, p. 26): "The discussion and exchange at the final monetary policy meeting do not start from scratch, but are the culmination and summary of [a long series of]...meetings. Therefore, one would not expect too much spontaneity but rather the presentation of the essential summaries and the reasons for the decision by each member."

It is once again worth emphasizing that last minute changes are possible. The work process is designed so that the forecasts and the Monetary Policy Report can be changed after the meeting if a majority of the MPC members so desires (see, e.g., Hallsten och Tägtström 2009).

We also put a follow-up question to the members, asking them how come they had a firm idea of how the others intended to vote. The responses to this question too support the hypothesis that publication of the Riksbank's own repo rate forecast has changed the monetary policy process and meant that more is in place prior to the meeting. Members of the "post-change" sample declared that the others' views more often became clear at the preparatory meetings (the average scores was 2.3 compared to 1.4 for the "pre-change" sample) and less often from the members' public statements $(0.5 \text { compared to } 1.3)^{7}$, or from the fact that the members have a predictable reaction pattern (0.8 compared to 1.5$)$. However, the publication of the repo rate path does not appear to have had any effect on how common it is for the members to obtain information on one another's views in discussions outside of the meetings, in private or in groups (the average scores were 1.4 in both samples).

\subsection{During the meeting: On the Chairman's role and the willingness to compromise}

\section{The Chairman's role}

On average, approximately one in three repo rate decisions has not been unanimous. Rather curiously, the only members that have never dissented are the sitting Governors. ${ }^{8}$ Part of the explanation why the Governor never has been in the minority is that he holds the casting vote in case of a tie. The casting vote has been used on four occasions since 1999. But even if four

\footnotetext{
${ }^{7}$ One explanation of why this figure is smaller in the "post-change" sample is probably that the Riksbank decided, in connection with the publication of its own repo rate forecasts, that MPC members would no longer "signal" in advance how they considered the repo rate should be set at the coming monetary policy meeting.

${ }^{8}$ Lars Heikensten dissented once, but that was before he was appointed Governor. The most recently-appointed member of the Riksbank's MPC, Karolina Ekholm, who joined in March 2009, had at the time of the survey not dissented, either.
} 
votes are required for the Governor to be in minority, it nevertheless appears somewhat surprising that this has never happened. ${ }^{9}$

The role of the Governor/Chairman has been discussed in different strands of the literature. In experimental studies, Blinder and Morgan (2008a, 2008b) find that groups with designated leaders do not outperform groups without leaders when playing a monetary policy game. Descriptive empirical studies have documented the dominating role of the Chairman, mostly in the Federal Reserve's Federal Open Market Committee; see, for instance, Chappell, McGregor and Vermilyea (2004, 2005, 2007a, 2007b). It is, for example, found that when Arthur Burns was the Chairman of the FOMC, his opinion counted about as much as all the other committee members put together. Like Greenspan, Burns was never on the losing side of a vote. An important source of this policymaking weight is reluctance among FOMC members to challenge the proposal offered by an agenda-setting Chairman. In terms of Blinder's (2004) taxonomy, the FOMC has previously been classified as an autocraticallycollegial committee, in which the meetings are very much controlled by the chairman. The present chairman, Ben Bernanke, appears however to be less dominant than his predecessors (Harris 2008).

Theoretical contributions have in different ways modelled and analyzed the consequences of the Chairman exerting a disproportionate influence, whether due to greater skills, being the agenda setter at the monetary policy meeting or just his position per se (see, for instance, Berk and Bierut 2007, Riboni and Ruge-Murcia 2007, Gerlach-Kristen 2008, Farvaque, Matsueda, and Méon 2009 and Claussen, Matsen, Røisland and Torvik 2009).

We asked the members to state how relevant they consider different explanations to be as to why the Governor of the Riksbank has never been in the minority:

- The Governor has more influence over the forecasts and other materials on which the interest rate decisions are based than the other members of the MPC.

- As the chairman at the monetary policy meeting the Governor is in a particularly good position to influence the discussion, and thereby the interest rate decision.

- Many members find it worthwhile to show unanimity and therefore support the Governor's view, given that it is reasonably close to their own assessment.

- The Governor finds it worthwhile not to be in a minority and therefore supports the majority view, given that it is reasonably close to his own assessment.

- It is merely a coincidence that the Governor never has been in the minority.

The members did not consider any of these explanations particularly convincing. The hypothesis that the Governor of the Riksbank has greater influence over forecasts and other background material received an average score of 1.2 and a median of 1 , where 1 represents "applies only to a slight extent". The explanations that members tend to support the Governor's views or the reverse, that the Governor tends to support the majority, received slightly higher scores - both an average of 1.5 and a median of 2 and 1.5 respectively (where 2 represents "applies to some extent"). The slightly higher scores for these explanations point to some willingness to compromise when making repo rate decisions.

\footnotetext{
${ }^{9}$ The results are similar for other central banks with individualistic committees. In the United Kingdom, for instance, the central bank governor has actually been voted down, although this had at the time of writing only happened on two out of more than 150 decision-making occasions (and where around 60 per cent of these have not resulted in a unanimous decision).
} 
The respondents seem to be particularly sceptical towards the hypothesis that the Governor as chairman at the monetary policy meeting can influence the discussion and thereby the interest rate decision (average score 0.8 and median 0.0). This result is well in line with the above result, namely that members have in principle decided before the meeting how they will vote. The results on the whole are in line with the Riksbank's MPC being an individualistic committee, in which the leader is only modestly more important than the other members. Yet, the results are somewhat inconclusive in that despite the fact that none of the above explanations are seen as very convincing, the "mere coincidence" explanation is considered irrelevant (average score 0.7 and median 0.0 ).

It seems reasonable to suspect that the more intense involvement of the MPC members in the preparatory process since the introduction of the repo rate forecasts in 2007 would have reduced the Governor's influence. A comparison of the "pre-change" and the "post-change" samples suggests that this is indeed what has happened, see Figure 6.

Figure 6. The role of the Governor/Chairman

At the Riksbank the Governor has never dissented. Why?

(Median response)

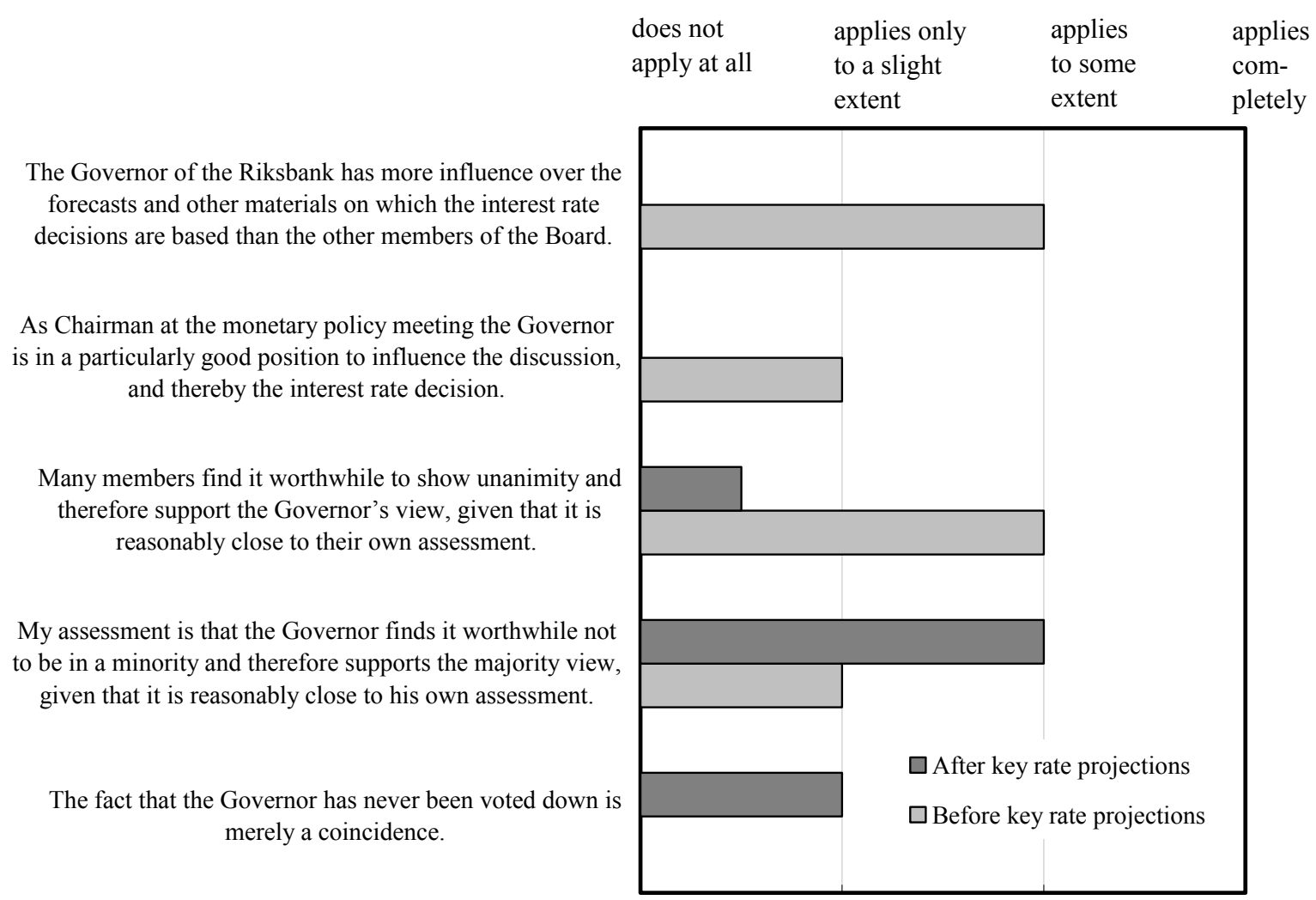

Members' willingness to compromise

Another issue we wanted to explore was if members sometimes might refrain from dissenting even in an individualistic committee, despite having a different opinion from the majority. This type of information is probably difficult to obtain in any other way than through a direct 
question; diverging opinions that do not result in a dissenting vote will probably not be very well expressed in, for instance, the minutes.

We asked the members the following question: Have you refrained from dissenting against one or more monetary policy decisions, despite the fact that you considered a different decision than that made by the majority would have been better? A majority of seven members responded that they had. We then asked for the relevance of some alternative reasons for refraining from dissenting. One of these reasons was assessed as much more important than the others, namely that the majority decision was reasonably close to their own assessment and that there was a "bargaining margin" in the repo rate decisions. According to all but one of the seven members, this reason is "very important". The other explanations received low average scores. However, some members state that they have refrained from dissenting out of consideration to the general public's confidence in monetary policy (average scores 1.0) or to avoid creating unease in the financial markets (average scores 0.4). One explanation that is dismissed by all is that the dissenting vote would change the majority and this in turn would lead to costs for changing the forecasts and reports at the last minute.

In an individualistic committee like the Riksbank's MPC disagreement is natural. Nevertheless, our results indicate that the members' own views must differ sufficiently from the majority view before they cast a dissenting vote - the members "choose their battles" and there is willingness to compromise. Thus, there is an apparent collegial element in the otherwise individualistic committee. The notion of a bargaining margin may also be interpreted as members considering monetary policy not to be a very exact science with definite answers.

\subsection{On communication: Attributed minutes and speeches}

\section{Attributed minutes}

How transparent a central bank should be is debated both within academic research and in central bank spheres (for reviews of the literature on transparency, see, for instance, Geraats 2002, 2006, Crowe and Meade 2008, and Blinder, Ehrmann, Fratzscher, de Haan and Jansen 2008). A major issue is whether or not minutes and the voting result of the monetary policy meeting should be published. Advocates argue that public minutes and voting results are necessary for effective monitoring and evaluation. Furthermore, and in particular if minutes and voting results are attributed, the members' individual responsibility becomes more apparent, strengthening the members incentives to prepare thoroughly for the meetings (Gersbach and Hahn 2008a). Public minutes and voting records may also make the bank's future behaviour easier to predict (see, e.g., Gerlach-Kristen 2004, 2009 for empirical support for this hypothesis).

The case against publishing minutes and voting results typically rests upon the assumption that this type of information may just confuse matters. For instance, Issing (2005) fears that economic agents will attach more importance to MPC members' individual opinions than to the relevant economic arguments: "Particularly in a monetary union comprising several countries, the voting behavior of national central bank governors in particular might be interpreted from a "national" perspective - irrespective of how the members cast their votes and their reasons for doing so." (Issing 2005, p. 73). In addition, publishing attributed minutes might have the effect of making the discussion at the policy meeting less honest and frank, and more limited and "tied to script". Attributed minutes may therefore make members want to hold pre-meetings, as discussed above. Meade and Stasavage (2008) provide some 
evidence from the Federal Reserve's Federal Open Market Committee that publishing verbatim transcripts of the FOMC meetings made members more reluctant to offer dissenting opinions. The pros and cons of revealing information about the deliberations of individual MPC members, for example by publishing individual voting records, have been explored in a number of theoretical papers (see, for instance, Gersbach and Hahn 2008b, 2009 and Weber 2008).

At the Riksbank, minutes are attributed (since May 2007) and published two weeks after the policy meeting. Since May 2009, the voting figures are made public at the same time as the interest rate decision along with information on who has dissented and their main reason for doing so. This means that the Riksbank has gone a step further than most (arguably all) other central banks. Hence, it might be useful to examine how the MPC members themselves perceive the situation.

The members were asked to react to four statements: That the discussion at the monetary policy meetings would be more inhibited and less spontaneous or in some other way poorer if the minutes are attributed; that the discussion would be better with attributed minutes; that the members would invest more time and work in the monetary policy preparation work with attributed minutes; and that there would be more focus on the individual members with attributed minutes.

The statement that is clearly negative towards attributed minutes - that the discussion become more inhibited and less spontaneous - is the one that receives least support, with an average of 1.1 and a median of 1 ("applies only to a slight extent"). The statement that attributed minutes make the discussion better receives the most support, with both an average score and a median of 2 ("applies to some extent"). For the other two statements the median is also 2, while the average scores are 1.4 and 1.7 respectively.

If one examines the responses in the same two samples as before, prior to and after publication of an own repo rate path (February 2007), which roughly coincides with the publication of attributed minutes (June 2007), it is clear that opinions appear to have changed slightly over time, see Figure 7 . The members who actually have experience of attributed minutes are more positive than those who do not.

The results are perhaps not surprising given that many of the members in the "post-change" sample have taken part in the decision to publish attributed minutes. The results should also be seen in light of the discussions at the monetary policy meeting being basically a summary of a series of meetings, where the individual members describe the reasons for the stance that they have in principle already decided on. It is plausible that it was previously the case that the situation prior to the monetary policy meeting was not as clear. The discussion at the actual meeting may then have played a more decisive role and members with experience of this period only may therefore be less positive to attributed minutes. It should be noted, however, that these members too believe that attributed minutes would improve the quality of the discussion during the policy meeting. 


\section{Figure 7. Attributed minutes}

How well do you think the following statements apply?

(Median response)

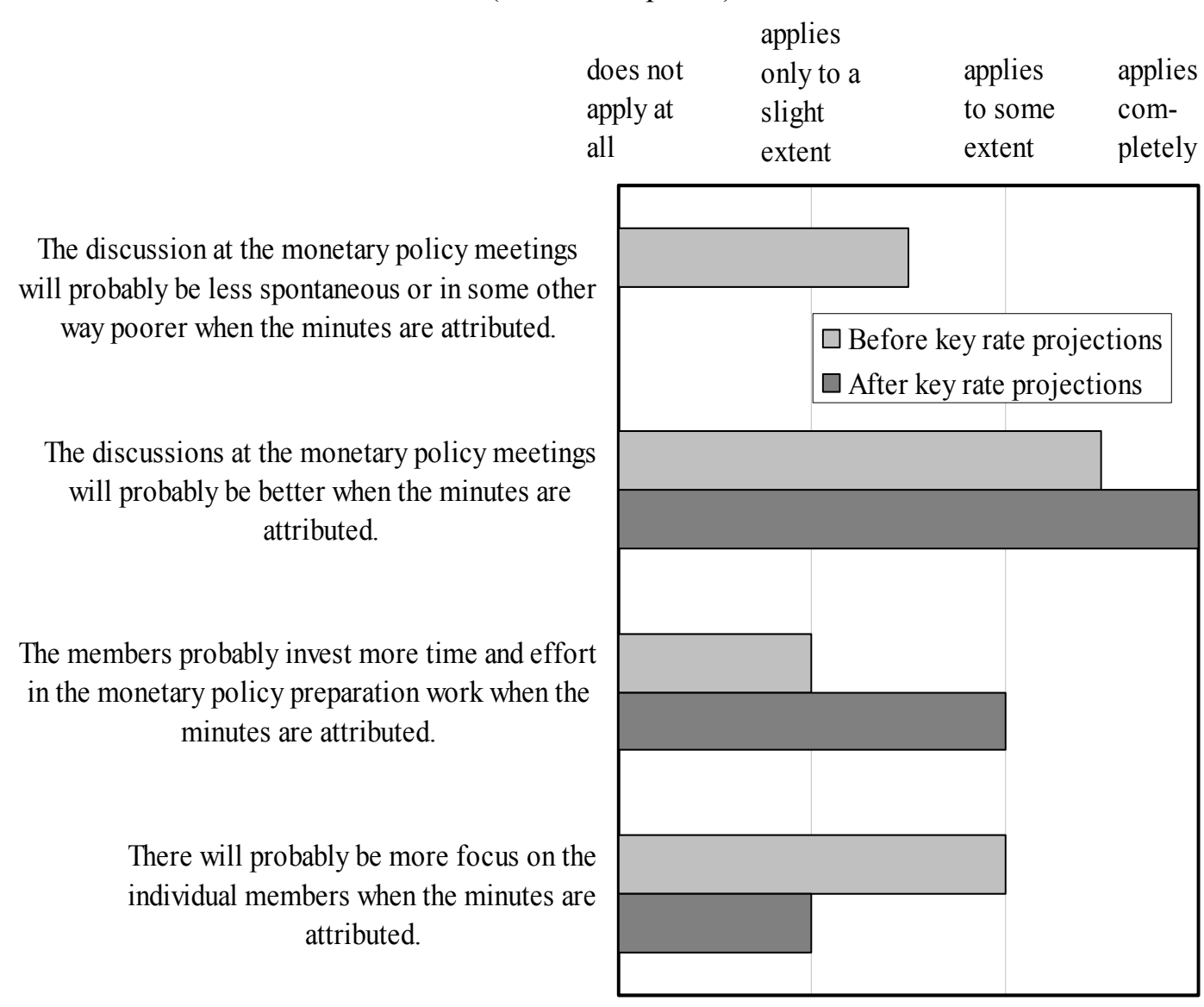

\section{Communication in speeches}

A closely related issue is how an MPC should communicate its policy in speeches. At the core of this issue - as of much of the transparency debate - is whether the MPC members should act as individuals or as a collective. As noted by Blinder, Ehrmann, Fratzscher, de Haan and Jansen (2008) MPCs have to strike a balance between two potentially opposing effects when communicating monetary policy. On the one hand information on the opinions of the different members helps explain the monetary policy decisions and can make monetary policy more predictable. On the other hand uncertainty may increase if members give different, conflicting signals. As Blinder (2007) put it: "A central bank that speaks with a cacophony of voices may, in effect, have no voice at all" (p. 114).

We asked the members to judge the following two statements:

- That all members of the Riksbank's MPC can express their own views publicly as individuals makes the Riksbank's communication less clear

- That each member publicly describes his or her views (for example, in speeches and the minutes of the meeting) is important so that economic agents will understand the Riksbank's policy ("the way we think"). 
The members were also asked to react to the statement

- I have felt bound by statements made by other members in public.

This latter statement is partly related to the first statement: To avoid the message being too fragmented, members may feel forced to keep quiet regarding their own view, or even to support, against their will, an opinion already expressed publicly by someone else.

The balance tipped in favour of the second argument, see Figure 8. The majority of the members consider it important that each member explains his or her opinions so that the economic agents will understand the Riksbank's policy (average score 2.5). The statement that communication may be unclear if all of the members of the Riksbank's MPC comment publicly receives less support, although only a couple of members dismiss this entirely (average score 1.3). A much larger number dismiss the statement that they have felt bound by other member's statements in public (average score 0.5$){ }^{10}$

\section{Figure 8. Communication in speeches}

How well do you think the following statements apply?

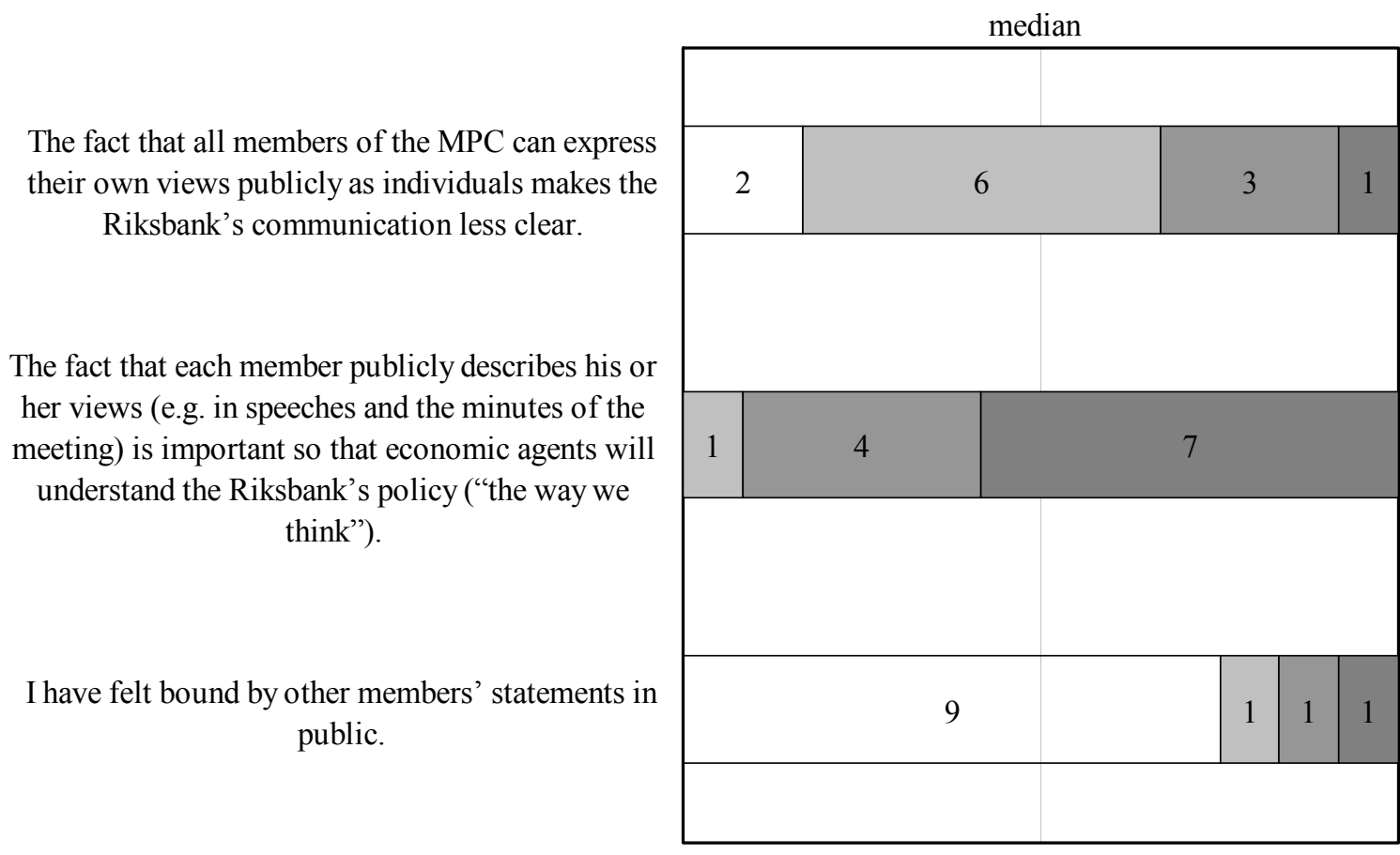

$\square$ does not apply at all $\square$ applies only to a slight extent $\square$ applies to some extent $\square$ applies completely

\footnotetext{
${ }^{10}$ Andersson, Dillén and Sellin (2006) investigate how various monetary policy signals such as repo rate changes, inflation reports, speeches, and minutes from monetary policy meetings affect the term structure of interest rates. They find that unexpected movements in the short end of the yield curve are mainly driven by unexpected changes in the repo rate. However, they also find that published inflation reports and speeches have some impact on short rates. Speeches are found to be a more important determinant for the longer end of the term structure.
} 


\subsection{On stabilising inflation and stabilising the real economy}

An issue that perhaps has not been that much discussed in the specific MPC literature but still is of general interest is how policymakers value stabilising inflation vs. stabilising the real economy. The Riksbank conducts what is called flexible inflation targeting, which means that it attempts to stabilise inflation around the target as well as to stabilise the real economy. The latter is often described as trying to stabilise some measure of resource utilisation in the economy around a normal level. Given the Riksbank's present approach, flexible inflation targeting involves the Riksbank setting a current repo rate and choosing a future repo rate path that give a forecast for inflation and resource utilisation that "looks good". Loosely speaking, this means that if one looks ahead, any deviation from the inflation target or deviation from the normal level of resource utilisation appears reasonable and not too large.

Theoretically, flexible inflation targeting can be described as choosing a repo rate path that will minimise a loss function

$$
L=\sum_{\tau=0}^{\infty}\left(\pi_{t+\tau, t}-\pi^{*}\right)^{2}+\lambda \sum_{\tau=0}^{\infty}\left(y_{t+\tau, t}-\bar{y}_{t+\tau, t}\right)^{2}
$$

where $\pi_{t+\tau, t}$ is the forecast in quarter $t$ for inflation in quarter $t+\tau, \pi^{*}$ is the inflation target, $\lambda$ is the weight given to stabilising resource utilisation relative to stabilising inflation, and $\left(y_{t+\tau, t}-\bar{y}_{t+\tau, t}\right)$ is a measure of resource utilisation (e.g. the output gap) (see, e.g., Svensson $2009 \mathrm{~b})$. It is thus a question of choosing a repo rate path that minimises the squared sum of the forecast for the inflation deviation $\sum_{\tau=0}^{\infty}\left(\pi_{t+\tau, t}-\pi^{*}\right)^{2}$, plus the weight $\lambda$ times the squared sum of the forecast for resource utilisation $\sum_{\tau=0}^{\infty}\left(y_{t+\tau, t}-\bar{y}_{t+\tau, t}\right)^{2}$.

Some have argued that arriving at one interest rate path is very difficult for a committee, particularly for a committee that is individualistic (see, for instance, Goodhart 2009). For example, different $\lambda$ 's among members could lead them to prefer different paths for the future repo rate. The difficulties in agreeing on an interest rate path are sometimes cited as one reason why relatively few central banks so far have chosen to publish their own interest rate forecasts. Evidently, the Riksbank has nevertheless found ways, at least so far, to make the monetary policy decision-making process result in a path for the repo rate that a majority of the members can support (Svensson 2009a).

Flexible inflation targeting as conducted by the Riksbank and other central banks is often described theoretically as above. But less is known about how actual monetary policy decision-makers look upon the links between theory and practice. The question we chose to focus on in the survey is to what extent the members are prepared to specify how much they value stabilising inflation in relation to stabilising the real economy - to reveal their $\lambda$.

We asked the members the following question (after a brief theoretical introduction):

- Would you consider - using your own judgement, or, for instance, the Riksbank's resources for analysis - stating in terms of a number how much importance you would 
normally place on stabilising resource utilisation in the economy in relation to stabilising inflation (that is, stating your $\lambda$ )?

Four of the members responded that they would consider this. Those who responded that they would not consider stating a $\lambda$ were asked to rate the following three explanations as to why they felt unable to do so: (i) The idea that one can use a specific number to describe the relative weight of stabilising inflation to stabilising resource utilisation is overly simple, (ii) the relative weight depends on the current situation and therefore varies so much that it is meaningless to state a number, and (iii) the measures of resource utilisation in the economy are so uncertain that it is meaningless to state a relative weight. All of the alternatives received considerable support with average scores of 2.9, 2.8 and 2.4, and the median 3 , "applies completely", for all explanations.

We then asked the eight members who did not consider that they could provide a specific figure for $\lambda$ whether they would be willing to provide a rough estimate of how they value stabilising inflation in relation to stabilising resource utilisation, more precisely if they could say that they would normally give greater importance to stabilising inflation than resource utilisation $(\lambda<1)$, less importance to stabilising inflation than resource utilisation $(\lambda>1)$ or roughly equal weight to stabilising inflation and resource utilisation $(\lambda \approx 1)$. Five members were willing to do so.

A total of nine members were thus prepared to at least make a rough estimate of much relative importance they would give to stabilising inflation in relation to stabilising resource utilisation. Five of these said that they would give more importance to stabilising inflation and four said that they would give roughly equal weight to stabilising inflation and stabilising resource utilisation, see Figure 9. None of them was willing to give greater importance to stabilising resource utilisation.

Figure 9. The weight on stabilisation of inflation vs. the real economy

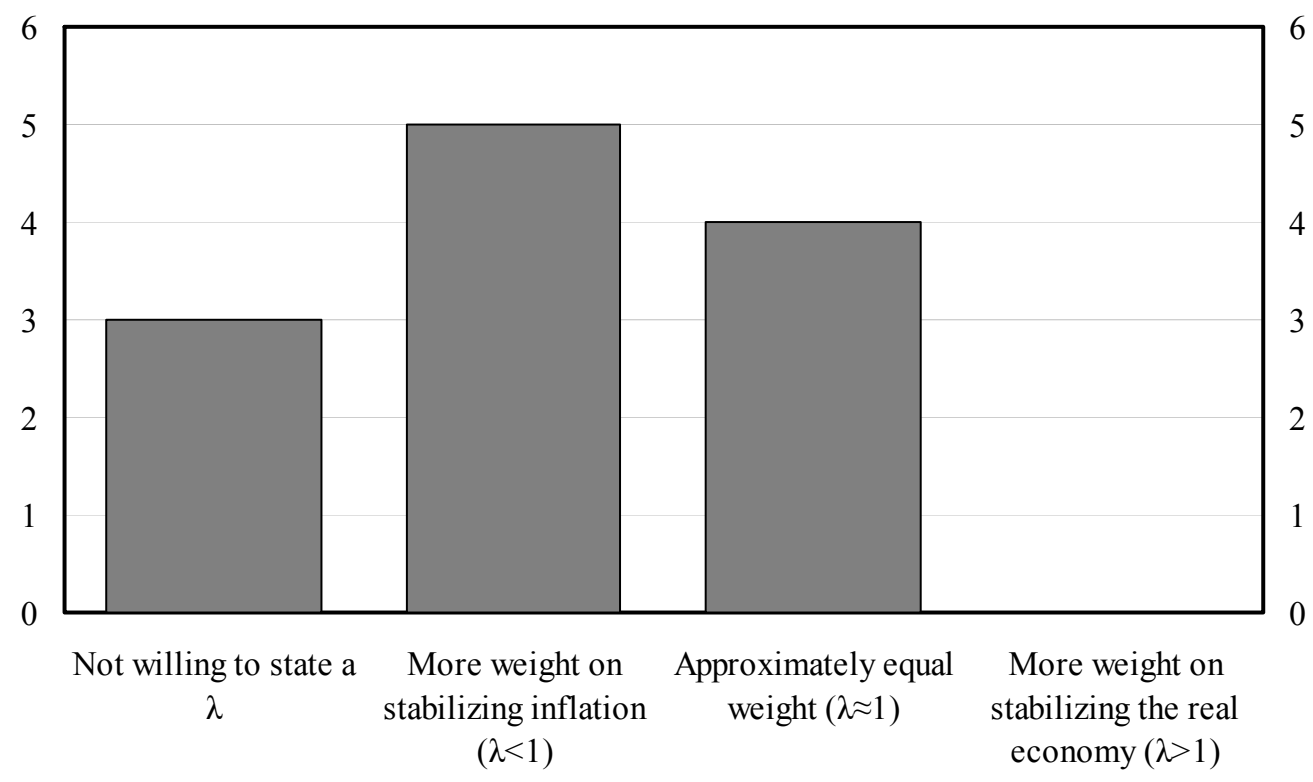


On the whole the results indicate that many members are sceptical towards far-reaching parallels between how monetary policy is described in economic theory and how it is actually conducted - that there are limits as to how far you can go in linking theory and practice. At the same time, it is striking how many considered that they could at least make a rough estimate of how much importance they give to stabilising inflation relative to stabilising resource utilisation.

\section{Summing up and concluding}

The questionnaire to present and former members of the Riksbank's MPC generated several noteworthy findings. To give some examples:

- Half of the respondents considered the six-person strong MPC to be too big from a monetary policy point of view;

- Although the repo rate decision is of course made at the monetary policy meeting, the members almost always seem to have made up their minds before the meeting, and it is only occasionally that new information or new arguments come up at the meeting. During the preparatory process the members also appeared have formed a good idea of how most of their colleagues intend to vote;

- When forming their opinions, members consider input from the staff more important than input from their colleagues;

- Despite the Riksbank's MPC being an individualistic committee, there is an element of collegiality in that there seems to be considerable willingness to compromise when setting the interest rate - many members have sometimes refrained from dissenting and indicate that there is a "bargaining margin" in the interest rate decisions;

- Three quarters of the respondents are willing to make at least a rough estimate of the relative weight they normally would give to stabilising inflation vs. resource utilization (the parameter "lambda" in the monetary policy loss function). Of these, a little more than half would give more weight to stabilising inflation and the rest would give approximately equal weight to stabilising inflation and stabilising resource utilization.

Several of the results in the survey appear to be linked in various ways to the monetary policy decision-making process at the Riksbank. This process differs somewhat from the stylized view of a monetary policy decision-making process that seems to dominate the research literature. In the stylized view, most of the focus is on the monetary policy meeting. A committee is gathered to one single meeting to discuss how the current policy rate should be set. Prior to the meeting there is little of interaction between the members and the discussion during the meeting is therefore crucial. Eventually, the committee reaches a decision as to whether or not the current policy rate needs to be changed, and if so by how much. The interest rate decision is announced and a relatively brief explanation is given.

The process at the Riksbank, in contrast, spans a number of weeks and involves a series of meetings, in which both the staff and the MPC members participate and discuss. The process concludes in a repo rate decision and forecasts for a number of central variables, including the future development of the repo rate. The forecasts and the monetary policy considerations are presented and explained in a detailed report that is published at the same time as the repo rate decision. 
In light of this process the survey result that much of the puzzle is completed before the monetary policy meeting should come as no surprise. It would rather be surprising if the MPC members after the series of preparatory meetings would not have formed their own opinion and got a pretty good picture of how their colleagues reason and deliberate. Furthermore, since a detailed report is published at the same time as the interest rate decision is announced, it is more or less necessary to work out forecasts and alternative scenarios on which a majority is likely to agree.

The decision-making process could also explain to some extent the relatively positive attitude to the attributed minutes found in the survey. The members have had the opportunity during the series of preparatory meetings to test their arguments on their colleagues and the staff, to hone them and possibly to revise them. The arguments can therefore be put forward in a concise and well-structured way at the monetary policy meeting. It is also possible that the apparent scepticism towards a system with external MPC members is partly due to the belief that it is important that all members take part in all stages of the monetary policy decisionmaking process.

It is probably not particularly unusual for central banks to work in a similar manner as the Riksbank - where forecasts and views on what should be done gradually emerge as the result of a series of meetings and are presented in a written report published at the same time as the policy rate decision. For example, in a study of the practices in 35 central banks Nelson (2008) finds that the preparations for a policy meeting takes on average about four weeks; that interactions between policymakers and the staff during this process is quite common, and has increased in recent years; and that nearly all banks in the sample publish an assessment (although not necessarily an extensive report) of the current economic situation, the shortterm outlook for the economy, and an assessment of the risks, along with the interest rate decision.

A decision making process like the one at the Riksbank thus seems no less representative, and is arguably more representative, than the stylized view. This in turn suggests that much of the results from the survey do not pertain solely to Swedish conditions. To possibly verify this and to further map the views of "real-life" monetary policy makers - which in itself would be valuable - similar studies on other MPCs would be useful. 


\section{References}

Andersson, M., H. Dillén and P. Sellin (2006), "Monetary Policy Signaling and Movements in the Term Structure of Interest Rates" Journal of Monetary Economics 53 (8), 1815-1855.

Apel, M., C. A. Claussen, and P. Lennartsdotter (2010), "The Executive Board of the Riksbank and its Work on Monetary Policy - Experiences from the First Ten Years." Sveriges Riksbank Economic Review No. 12010.

Berger, H., and V. Nitsch (2008), "Too Many Cooks? Committees in Monetary Policy." Working Paper no. 2274. CESifo GmbH.

Berger, H., V. Nitsch, and T. Lybek (2008), "Central Bank Boards Around the World: Why does Membership Size Differ?” European Journal of Political Economy 24(4), 817-832.

Berk, J. M., and B. K. Bierut (2007), "Two-Tiered MPCs and the Implications for Monetary Policy." Paper presented at the Norges Bank Conference on Monetary Policy Committees, Oslo, Norway, 6-7 September.

Besley, T., N. Meads, and P. Surico (2008), "Insiders versus Outsiders in Monetary Policymaking.” American Economic Review: Papers and Proceedings 98(2), 218-223.

Blinder, A. S. (2004), The Quiet Revolution: Central Banking Goes Modern, Yale University Press.

Blinder, A. S. (2007), "Monetary Policy by Committee: Why and How?" European Journal of Political Economy 23, 106-123.

Blinder, A. S. (2009), “Making Monetary Policy by Committee.” International Finance 12(2), 171-194.

Blinder, A. S., and J. Morgan (2005), "Are Two Heads Better Than One? Monetary Policy by Committee." Journal of Money, Credit, and Banking 37(5), 789-812.

Blinder, A. S., and J. Morgan (2008a), "Do Monetary Policy Committees Need Leaders? A Report on an Experiment." American Economic Review 98(2), 224-29.

Blinder, A. S., and J. Morgan (2008b), 'Leadership in Groups: A Monetary Policy Experiment." International Journal of Central Banking 4(4), 117-150.

Blinder, A. S., M. Ehrmann, M. Fratzscher, J. De Haan, and D.-J. Jansen (2008), ”Central Bank Communication and Monetary Policy: A Survey of Theory and Evidence." Journal of Economic Literature 46(4), 910-945.

Chappell, H. W. Jr., R. R. McGregor, and T. Vermilyea (2004), "Majority Rule, Consensus Building, and the Power of the Chairman: Arthur Burns and the FOMC." Journal of Money, Credit and Banking 36(3), 407-422.

Chappell, H. W. Jr., R. R. McGregor, and T. Vermilyea (2005), Committee Decisions on Monetary Policy: Evidence from Historical Records of the Federal Open market Committee, MIT Press. 
Chappell, H. W. Jr., R. R. McGregor, and T. Vermilyea (2007a), "The Persuasive Power of a Committee Chairman: Arthur Burns and the FOMC." Public Choice 132(1-2), 103-112.

Chappell, H. W. Jr., R. R. McGregor, and T. Vermilyea (2007b), "The Role of the Bias in Crafting Consensus: FOMC Decision Making in the Greenspan Era." International Journal of Central Banking 3(2), 39-60.

Claussen, C. A., E. Matsen, Ø. Røisland, and R. Torvik (2009), "Overconfidence, Monetary Policy Committees and Chairman Dominance." Working paper 2009/17, Norges Bank.

Crowe, C., and E. E. Meade (2008), "Central bank Independence and Transparency: Evolution and Effectiveness." European Journal of Political Economy 24, 763-777.

Dincer, N., and B. Eichengreen (2007), "Central Bank Transparency: Where, Why, and With What Effects?" Working Paper no. 13003, National Bureau of Economic Research.

Dincer, N., and B. Eichengreen (2009), "Central Bank Transparency: Causes, Consequences and Updates." Working paper no. 14791, National Bureau of Economic Research.

Eijffinger, S. C. W., and P. M. Geraats (2006), "How Transparent are Central Banks?" European Journal of Political Economy 22(1), 1-21.

Erhart, S., and J.-L. Vasquez-Paz (2007), "Optimal Monetary Policy Committee Size: Theory and Cross Country Evidence.” Working Paper no. 2007/6, The Central Bank of Hungary.

Erhart, S., H. Lehment, and J.-L. Vasquez-Paz (2007), "Monetary Policy Committee Size and Inflation Volatility.” Kiel Working Paper No. 1377, Kiel Institute for the World Economy.

Farvaque, E., N. Matsueda, and P.-G. Méon (2009), "How Committees Reduce the Volatility of Policy Rates.” Journal of Macroeconomics 31 (4), 534-546.

Geraats, P. (2002), “Central Bank Transparency.” The Economic Journal 112 (November), F532-F565.

Geraats, P. (2006), "Transparency of Monetary Policy: Theory and Practice.” CESifo Economic Studies 52(1), 111-152.

Gerlach-Kristen, P. (2003), 'Insiders and Outsiders at the Bank of England." Central Banking XIV, 96-102.

Gerlach-Kristen, P. (2004), “Is the MPC's Voting Record Informative About Future UK Monetary Policy?" Scandinavian Journal of Economics 106(2), 299-313.

Gerlach-Kristen, P. (2008), "The Role of the Chairman in Setting Monetary Policy: Individualistic vs. Autocratically Collegial MPCs." International Journal of Central Banking 4(3), 119-143.

Gerlach-Kristen, P. (2009), "Outsiders at the Bank of England's MPC.” Journal of Money, Credit and Banking 41(6), 1099-1115. 
Gerling, K., H. P. Grüner, A. Kiel, and E. Schulte (2005), "Information Acquisition and Decision Making in Committees: A Survey." European Journal of Political Economy 21, 563-597.

Gersbach, H., and V. Hahn (2008a), "Information Acquisition and Transparency in Committees.” Discussion Papers nr. 6677, Centre for Economic Policy Research.

Gersbach, H., and V. Hahn (2008b), "Should the Individual Voting Records of Central Bankers be Published?" Social Choice and Welfare 30(4), 655-683.

Gersbach, H., and V. Hahn (2009), "Voting Transparency in a Monetary Union." Journal of Money, Credit and Banking 41(5), 831-853.

Goodhart, C. (2009), “The Interest Rate Conditioning Assumption.” International Journal of Central Banking 5(2), 85-108.

Groth, C., and T. Wheeler (2008), "The Behaviour of the MPC: Gradualism, Inaction and Individual Voting Patterns." External MPC Unit Discussion Paper No. 21. Bank of England.

Hallsten, K., and S. Tägtström (2009), "The Decision-Making Process - How the Executive Board of the Riksbank Decides on the Repo Rate." Sveriges Riksbank Economic Review No. 1 2009, 69-86.

Hammond, G. (2009), "State of the Art of Inflation Targeting", Handbook No. 29, Bank of England, Centre for Central Banking Studies.

Hansen, S., and M. F. McMahon (2008), ”Delayed Doves: MPC Voting Behaviour of Externals." CEP Discussion Papers DP0862, Centre for Economic Performance, London School of Economics.

Harris, E. S. (2008), Ben Bernanke’s Fed: The Federal Reserve After Greenspan. Boston: Harvard Business Press.

Harris, M., and C. Spencer (2008), "Decade of Dissent: Explaining the Dissent Voting Behaviour of Bank of England MPC Members.” MPRA Paper No. 9100, University Library of Munich.

Issing, O. (2005), "Communication, Transparency, Accountability: Monetary Policy in the Twenty-First Century." Federal Reserve Bank of St. Louis Review 87(2, Part 1), 65-83.

Lombardelli, C., J. Proudman, and J. Talbot (2005), "Committees Versus Individuals: An Experimental Analysis of Monetary Policy Decision-Making." International Journal of Central Banking 1(1), 181-205.

Maier, P. (2007), "Monetary Policy Committees in Action: Is There Room for Improvement?" Bank of Canada Working Paper 2007-6.

Meade, E. E., and D. Stasavage (2008), "Publicity of Debate and the Incentive to Dissent: Evidence from the US Federal Reserve.” The Economic Journal 118(April), 695-717. 
Nelson, W. (2008), "Monetary Policy Decisions: Preparing the Inputs and Communicating the Outcomes." BIS Papers No 37.

Riboni, A., and F. J. Ruge-Murcia (2007), "Monetary Policy by Committee: Consensus versus Chairman Dominance." Paper presented at the Norges Bank Conference on Monetary Policy Committees, Oslo, Norway, 6-7 September.

Sibert, A. (2006), ”Central Banking by Committee.” International Finance 9(2):145-168.

Svensson, L. E. O. (2009a), “Transparency Under Inflation Targeting: Experiences and Challenges.” Sveriges Riksbank Economic Review No. 1 2009, 5-44.

Svensson, L. E. O. (2009b), "Evaluating Monetary Policy.” NBER Working Paper No. 15385.

Swank, O. H., and B. Visser (2008), "Is Transparency to No Avail? Committee DecisionMaking, Pre-Meeting, and Credible Deals.” EUI Working Papers ECO 2008/18, European University Institute.

Swank, J., O. H. Swank, and B. Visser (2008), "How Committees of Experts Interact with the Outside World: Some Theory, and Evidence from the FOMC." Journal of the European Economic Association 6(2-3), 478-486.

Weber, A. (2008), "Communication, Decision-Making and the Optimal Degree of Transparency of Monetary Policy Committees." Discussion Paper Series 1: Economic Studies No 02/2008, Deutsche Bundesbank. 


\section{Appendix A}

1. Why an Executive Board

If you look at your own experiences of Swedish conditions and of the Riksbank's Executive Board, how well would you say that you agree with the following statements? (not at all=0, agree slightly=1, agree to some extent $=2$, agree entirely $=3$ )

To gain sufficient acceptance among the general public and politicians for a system where the Riksbank is independent requires that the monetary policy decisions are made by a group of persons and not by one individual.

Over time the monetary policy decisions improve if they are made by a group of persons instead of by one individual.

If you have responded that you "agree entirely" or "agree to some extent" that the monetary policy decisions improve if they are made by a group of persons, how important are the following reasons for your response? (unimportant $=0$, slightly important $=1$, fairly important $=2$, very important $=3$ )

When the Executive Board, a group of persons with different backgrounds, experiences and skills, discusses and interacts, the basis

1.3 for decision-making is enriched and the decisions are better than what even the most competent member of the Executive Board could achieve alone. A "collective wisdom" is created.

The fact that a group of persons with different backgrounds,

1.4 experiences and skills votes on the decisions means that they are better than they would have been if made by one individual.

That the decisions are made by a group of persons functions as an

1.5 insurance against extreme preferences held by one individual governing monetary policy.

1.6 Other

\section{The role of the Executive Board and the staff}

How important were/are your colleagues on the Executive Board to you... (unimportant $=0$, slightly important $=1$, fairly important $=2$, very important=3)

...as sources of information on the current economic situation and on developing trends that the Riksbank is unable to influence, such as the

2.1 way the oil price and international economic activity develop? 
...for your view on how the Swedish economy functions and thereby

2.2 how things will develop if the Riksbank acts in one particular way or another?

...for your assessment of how quickly inflation should be brought back

2.3 on target/prioritising between stabilising inflation and stabilising the real economy?

How important were/are the staff to you... (unimportant=0, slightly important=1, fairly important $=2$, very important $=3$ )

....as a source of information on the current economic situation and on developing trends that the Riksbank is unable to influence, such as the

2.4 way the oil price and international economic activity develop?

... for your view on how the Swedish economy functions and thereby

2.5 how things will develop if the Riksbank acts in one particular way or another?

...for your assessment of how quickly inflation should be brought back

2.6 on target/prioritising between stabilising inflation and stabilising the real economy?

\section{The size and composition of the Executive Board}

My perception is that the Executive Board of the Riksbank - as a

3.1 monetary policy committee - was/is... (the figures refer to the total number of members who have marked the applicable category)

$\begin{array}{rll}\text { too small } & 1 & 1 \\ \text { the right size } & 5 & 5 \\ \text { too large } & 6 & 6\end{array}$

If you wish, state what you believe to be the most appropriate number

3.2 of members for the Executive Board, seen from a monetary policy

perspective

How well do you think that the following statements apply? (does not apply at all=0, applies only to a slight extent $=1$, applies to some extent $=2$, applies completely $=3$ )

The total background material for monetary policy would be better if one or more of the six members of the Riksbank's Executive Board

3.3 were external and could thereby contribute information, knowledge and an "external" perspective that would otherwise not be taken into account.

If one or more of the six members of the Riksbank's Executive Board was employed part-time, this would require less resources without the monetary policy decisions being of poorer quality. 


\section{The interest rate decisions}

How often has it happened that... (never $=0$, sometimes $=1$, often=2, always $=3$ )

...you have in principle decided how you intend to vote before the

4.1 monetary policy meeting and not changed your mind during the meeting?

...information and arguments that are new to you have been presented at the monetary policy meeting?

...you have changed your mind during the monetary policy meeting

4.3 despite the fact that you had in principle decided before the meeting how you intended to vote?

clear impression of how the majority of your colleagues intend to vote before you go into the monetary policy meeting?

...you have a clear impression of how all of your colleagues intend to

If you have responded that you "sometimes", "often" or "always" have a clear impression of how the majority of, or all of, your colleagues intend to vote, why is this? (never $=0$, sometimes $=1$, often=2, always $=3$ )

4.7 It has become clear at the preparatory meetings, such as the meetings of the monetary policy group.

4.8 It has become clear when we have discussed monetary policy with one another outside of the meetings, either bilaterally or in a group.

4.9 It has become clear from the members' public statements.

4.10 The members have a predictable reaction pattern.

4.11 Other:

\section{The role of the minutes}

Why is it important that the Riksbank publishes the minutes of the meeting soon after the monetary policy meeting has been held, unlike the ECB, for instance, which publishes the minutes after 30 years? (unimportant $=0$, slightly important $=1$, fairly important $=2$, very important=3)

It is necessary to provide reasons and explanations for the monetary policy decisions.

5.2 The minutes of the meetings provide signals of future monetary policy. 


\section{Expressing reservations in the minutes}

If you have entered a reservation against one or more interest rate decisions, how important were the reasons before for your stance? (unimportant $=0$, slightly important $=1$, fairly important $=2$, very important=3)

I made a different assessment of the current economic situation and of

6.1 developing trends that the Riksbank is unable to influence, such as the way the oil price and international economic activity develop

I made a different assessments of how the Swedish economy functions

6.2 and thereby how things will develop if the Riksbank acts in one particular way or another

I made a different assessment of how quickly inflation should be

6.3 brought back on target/prioritisation between stabilising inflation and stabilising the real economy

6.4 Other

Have you refrained from entering a reservation against one or more monetary policy decisions despite the fact that you considered a

6.5 different decision than that made by the majority would have been better? (The figures refer to the total number of members who have marked the applicable category)

If your response to question 6.5 above is "yes", how important were the reasons below for your decision? (unimportant $=0$, slightly important $=1$, fairly important $=2$, very important $=3$ )

6.6 The majority decision was reasonably close to my own assessment.

There is a "bargaining margin" in the interest rate decisions.
6.7 Consideration for the general public's confidence in monetary policy

$1.0 \quad 0.0$

6.8 Consideration to avoiding unease on the financial markets

$0.4 \quad 0.0$

My reservation would have changed the majority and the cost of

6.9 changing forecasts, texts and diagrams in the Monetary Policy Report/Update at the last minute would have been too great.

Risk of being misinterpreted externally. The reasons why I actually

6.10 wanted to enter a reservation were too difficult to communicate/elaborate properly.

My reservation would have changed the majority and the Governor would have been in the minority. 
At the Bank of England, for instance, the Governor has on several occasions been in the minority. However, at the Riksbank the Governor has never entered a reservation against an interest rate decision; although it has sometimes happened that his casting vote has been decisive (all of the other members of the Executive Board have entered a reservation at least once).

How well do you think the following explanations apply to this? (does not apply at all $=0$, applies only to a slight extent $=1$, applies to some extent $=2$, applies completely $=3$ )

The Governor of the Riksbank has more influence over the forecasts

6.13 and other materials on which the interest rate decisions are based than the other members of the Board.

As Chairman at the monetary policy meeting the Governor is in a

6.14 particularly good position to influence the discussion, and thereby the interest rate decision.

Many members find it worthwhile to show unanimity and therefore

6.15 support the Governor's view, given that it is reasonably close to their own assessment.

My assessment is that the Governor finds it worthwhile not to be in a

6.16 minority and therefore supports the majority view, given that it is reasonably close to his own assessment.

6.17 The fact that the Governor has never been voted down is merely a coincidence.

$0.7 \quad 0.0$

6.18 Other

\section{$7 \quad$ Attributed minutes}

If you have been on the Executive Board only prior to or only after the introduction of attributed minutes, how well do you think that the following statements apply? (does not apply at all=0, applies only to a slight extent $=1$, applies to some extent $=2$, applies completely $=3$ )

The discussion at the monetary policy meetings will probably be less

7.1 spontaneous or in some other way poorer when the minutes are attributed.

The discussions at the monetary policy meetings will probably be

7.2 better when the minutes are attributed.

The members probably invest more time and effort in the monetary

7.3 policy preparation work when the minutes are attributed.

There will probably be more focus on the individual members when 


\section{Communication}

How well do you think that the following statements apply? (does not apply at all $=0$, applies only to a slight extent $=1$, applies to some extent $=2$, applies completely $=3$ )

The fact that all members of the Executive Board can express their own

8.1 views publicly as individuals makes the Riksbank's communication less clear

8.2 I have felt bound by other members' statements in public.

$0.5 \quad 0.0$

The fact that each member public describes his or her views (e.g. in

8.3 speeches and the minutes of the meeting) is important so that economic agents will understand the Riksbank's policy ("the way we think").

8.4 Other

\section{The weight of stabilising inflation and the real economy} respectively

Would you consider - using your own judgement, or, for instance, the Riksbank's analysis resources - stating in terms of a figure how much importance you would normally place on stabilising resource

9.1 utilisation in the economy in relation to stabilising inflation (i.e. state your $\lambda$ )? (The figures refer to the total number of members who have marked the applicable category)

$\begin{array}{rrr}\text { yes } & 4 & 4 \\ \text { no } & 8 & 8\end{array}$

You do not need to state a figure, but you may of course do so if you wish:

If you have responded "no" to the above question, how well do you feel the following statements agree with the motives behind your response? (does not apply at all $=0$, applies only to a slight extent $=1$, applies to some extent $=2$, applies completely=3)

The idea that one can use a figure to explain the relative weight of

9.2 stabilising inflation against that of stabilising resource utilisation in the economy is overly simple.

The relative weight I would put on stabilising inflation in relation to stabilising resource utilisation would depend on the situation in the

9.3 economy. The relative weight therefore varies so much that it is meaningless to state a figure.

The measures of resource utilisation in the economy are so uncertain 
weight you would normally give to stabilising inflation in relation to stabilising resource utilisation, could you nevertheless make a rough estimate (see below)? (The figures refer to the total number of members who have marked the applicable category)

$\begin{array}{rll}\text { yes } & 9 & 9 \\ \text { no } & 2 & 2\end{array}$

If "yes", which of the alternatives below applies to how you would normally value stability in inflation relative to stability in resource utilisation? (The figures refer to the total number of members who have marked the applicable category)

9.7 I would give greater weight to stabilising inflation than to stabilising resource utilisation $(\lambda<1)$.

I would give less weight to stabilising inflation than to stabilising

9.8 resource utilisation $(\lambda>1)$.

I would give roughly equal weight to stabilising inflation as to stabilising resource utilisation $(\lambda=1)$ 


\section{Appendix B}

Table A1. The Riksbank’s MPC (The Executive Board) 1999-2009

1 January 1999-31 December 2000

1 January 2001-30 April 2001

1 May 2001-31 December 2002

1 January 2003-31 December 2005

1 January 2006-29 March 2007

30 March 2007-30 April 2007

1 May 2007-20 May 2007

21 May 2007-31 December 2008

1 January 2009-14 March 2009

15 March 2009-

\section{Governor Urban Bäckström}

Lars Heikensten, Eva Srejber, Villy Bergström, Kerstin Hessius, Lars Nyberg

Lars Heikensten, Eva Srejber, Villy Bergström, Lars Nyberg Lars Heikensten, Eva Srejber, Villy Bergström, Lars Nyberg, Kristina Persson

\section{Governor Lars Heikensten}

Eva Srejber, Villy Bergström, Lars Nyberg, Kristina Persson, Irma Rosenberg

\section{Governor Stefan Ingves}

Eva Srejber, Lars Nyberg, Kristina Persson, Irma Rosenberg, Svante Öberg

Irma Rosenberg, Lars Nyberg, Kristina Persson, Svante Öberg Irma Rosenberg, Lars Nyberg, Svante Öberg Irma Rosenberg, Lars Nyberg, Svante Öberg, Lars E O Svensson, Barbro Wickman-Parak

Svante Öberg, Lars Nyberg, Lars E O Svensson, Barbro WickmanParak

Svante Öberg, Lars Nyberg, Lars E O Svensson, Barbro WickmanParak, Karolina Ekholm 


\section{Earlier Working Papers:}

For a complete list of Working Papers published by Sveriges Riksbank, see www.riksbank.se

Estimation of an Adaptive Stock Market Model with Heterogeneous Agents by Henrik Amilon ........ 2005:177

Some Further Evidence on Interest-Rate Smoothing: The Role of Measurement

Errors in the Output Gap by Mikael Apel and Per Jansson.....

Bayesian Estimation of an Open Economy DSGE Model with Incomplete Pass-Through

by Malin Adolfson, Stefan Laséen, Jesper Lindé and Mattias Villani

Are Constant Interest Rate Forecasts Modest Interventions? Evidence from

an Estimated Open Economy DSGE Model of the Euro Area by Malin Adolfson,

Stefan Laséen, Jesper Lindé and Mattias Villani

Inference in Vector Autoregressive Models with an Informative

Prior on the Steady State by Mattias Villani

Bank Mergers, Competition and Liquidity by Elena Carletti, Philipp Hartmann

and Giancarlo Spagnolo

Testing Near-Rationality using Detailed Survey Data

by Michael F. Bryan and Stefan Palmqvist.

Exploring Interactions between Real Activity and the Financial Stance

by Tor Jacobson, Jesper Lindé and Kasper Roszbach

Two-Sided Network Effects, Bank Interchange Fees,

and the Allocation of Fixed Costs by Mats A. Bergman .....

Trade Deficits in the Baltic States: How Long Will the Party Last?

by Rudolfs Bems and Kristian Jönsson.

Real Exchange Rate and Consumption Fluctuations follwing Trade Liberalization

by Kristian Jönsson

Modern Forecasting Models in Action: Improving Macroeconomic Analyses at Central Banks

by Malin Adolfson, Michael K. Andersson, Jesper Lindé, Mattias Villani and Anders Vredin.....

Bayesian Inference of General Linear Restrictions on the Cointegration Space by Mattias Villani.

2005:189

Forecasting Performance of an Open Economy Dynamic Stochastic General Equilibrium Model

by Malin Adolfson, Stefan Laséen, Jesper Lindé and Mattias Villani

Forecast Combination and Model Averaging using Predictive Measures

by Jana Eklund and Sune Karlsson.

Swedish Intervention and the Krona Float, 1993-2002

by Owen F. Humpage and Javiera Ragnartz

A Simultaneous Model of the Swedish Krona, the US Dollar and the Euro

by Hans Lindblad and Peter Sellin

Testing Theories of Job Creation: Does Supply Create Its Own Demand?

by Mikael Carlsson, Stefan Eriksson and Nils Gottfries.....

Down or Out: Assessing The Welfare Costs of Household Investment Mistakes

by Laurent E. Calvet, John Y. Campbell and Paolo Sodini

Efficient Bayesian Inference for Multiple Change-Point and Mixture Innovation Models

by Paolo Giordani and Robert Kohn

Derivation and Estimation of a New Keynesian Phillips Curve in a Small Open Economy

by Karolina Holmberg

Technology Shocks and the Labour-Input Response: Evidence from Firm-Level Data

by Mikael Carlsson and Jon Smedsaas

Monetary Policy and Staggered Wage Bargaining when Prices are Sticky

by Mikael Carlsson and Andreas Westermark

The Swedish External Position and the Krona by Philip R. Lane

Price Setting Transactions and the Role of Denominating Currency in FX Markets

by Richard Friberg and Fredrik Wilander.....

The geography of asset holdings: Evidence from Sweden

by Nicolas Coeurdacier and Philippe Martin

Evaluating An Estimated New Keynesian Small Open Economy Model

by Malin Adolfson, Stefan Laséen, Jesper Lindé and Mattias Villani .......

The Use of Cash and the Size of the Shadow Economy in Sweden

by Gabriela Guibourg and Björn Segendorf

Bank supervision Russian style: Evidence of conflicts between micro- and macro-

prudential concerns by Sophie Claeys and Koen Schoors 
Optimal Monetary Policy under Downward Nominal Wage Rigidity

by Mikael Carlsson and Andreas Westermark

Financial Structure, Managerial Compensation and Monitoring

by Vittoria Cerasi and Sonja Daltung

Financial Frictions, Investment and Tobin's q by Guido Lorenzoni and Karl Walentin

Sticky Information vs. Sticky Prices: A Horse Race in a DSGE Framework

by Mathias Trabandt

Acquisition versus greenfield: The impact of the mode of foreign bank entry

on information and bank lending rates by Sophie Claeys and Christa Hainz

Nonparametric Regression Density Estimation Using Smoothly Varying Normal Mixtures

by Mattias Villani, Robert Kohn and Paolo Giordani

The Costs of Paying - Private and Social Costs of Cash and Card

by Mats Bergman, Gabriella Guibourg and Björn Segendorf....

Using a New Open Economy Macroeconomics model to make real nominal

exchange rate forecasts by Peter Sellin

Introducing Financial Frictions and Unemployment into a Small Open Economy Model

by Lawrence J. Christiano, Mathias Trabandt and Karl Walentin.....

Earnings Inequality and the Equity Premium by Karl Walentin

2007:215

Bayesian forecast combination for VAR models by Michael $K$ Andersson and Sune Karlsson

2007:216

Do Central Banks React to House Prices?

by Daria Finocchiaro and Virginia Queijo von Heideken

The Riksbank's Forecasting Performance

by Michael K. Andersson, Gustav Karlsson and Josef Svensson

Macroeconomic Impact on Expected Default Freqency

by Per Åsberg and Hovick Shahnazarian

Monetary Policy Regimes and the Volatility of Long-Term Interest Rates

by Virginia Queijo von Heideken

Governing the Governors: A Clinical Study of Central Banks

by Lars Frisell, Kasper Roszbach and Giancarlo Spagnolo ....

The Monetary Policy Decision-Making Process and the Term Structure of Interest Rates by Hans Dillén

How Important are Financial Frictions in the U.S. and the Euro Area

by Virginia Queijo von Heideken

Block Kalman filtering for large-scale DSGE models by Ingvar Strid and Karl Walentin 2008:224

Optimal Monetary Policy in an Operational Medium-Sized DSGE Model

by Malin Adolfson, Stefan Laséen, Jesper Lindé and Lars E.O. Svensson

Firm Default and Aggregate Fluctuations by Tor Jacobson, Rikard Kindell, Jesper Lindé and Kasper Roszbach

Re-Evaluating Swedish Membership in EMU: Evidence from an Estimated Model

by Ulf Söderström

The Effect of Cash Flow on Investment: An Empirical Test of the Balance Sheet Channel

by Ola Melander

Expectation Driven Business Cycles with Limited Enforcement

by Karl Walentin

Effects of Organizational Change on Firm Productivity

by Christina Håkanson

Evaluating Microfoundations for Aggregate Price Rigidities: Evidence from Matched Firm-Level

Data on Product Prices and Unit Labor Cost by Mikael Carlsson and Oskar Nordström Skans

Monetary Policy Trade-Offs in an Estimated Open-Economy DSGE Mode

by Malin Adolfson, Stefan Laséen, Jesper Lindé and Lars E.O. Svensson

Flexible Modeling of Conditional Distributions Using Smooth Mixtures of Asymmetric

Student T Densities by Feng Li, Mattias Villani and Robert Kohn.

Forecasting Macroeconomic Time Series with Locally Adaptive Signal Extraction

by Paolo Giordani and Mattias Villani.....

Evaluating Monetary Policy by Lars E.O. Svensson 2009:235

Risk Premiums and Macroeconomic Dynamics in a Heterogeneous Agent Model by Ferre De Graeve, Maarten Dossche, Marina Emiris, Henri Sneessens and Raf Wouters 2010:236 
Sveriges Riksbank

Visiting address: Brunkebergs torg 11

Mail address: se-103 37 Stockholm

Website: www.riksbank.se

Telephone: +46878700 00, Fax: +468210531

E-mail: registratorn@riksbank.se 